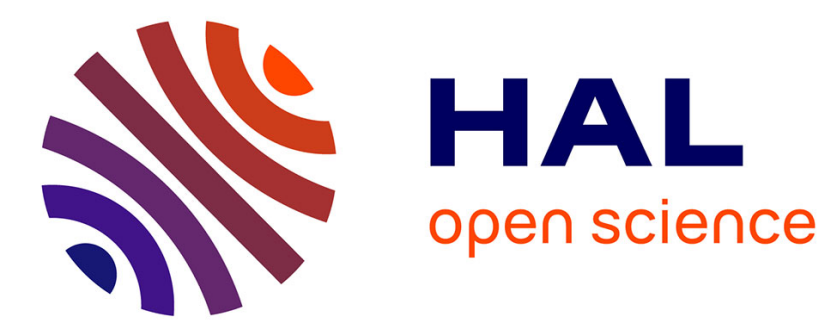

\title{
2-methoxyestradiol: New perspectives in colon carcinoma treatment
}

Michele Parks, Micol Tillhon, Francesca Donà, Ennio Prosperi, A. Ivana

Scovassi

\section{- To cite this version:}

Michele Parks, Micol Tillhon, Francesca Donà, Ennio Prosperi, A. Ivana Scovassi. 2-methoxyestradiol: New perspectives in colon carcinoma treatment. Molecular and Cellular Endocrinology, 2010, 331 (1), pp.119. 10.1016/j.mce.2010.08.017 . hal-00639766

\section{HAL Id: hal-00639766 https://hal.science/hal-00639766}

Submitted on 10 Nov 2011

HAL is a multi-disciplinary open access archive for the deposit and dissemination of scientific research documents, whether they are published or not. The documents may come from teaching and research institutions in France or abroad, or from public or private research centers.
L'archive ouverte pluridisciplinaire HAL, est destinée au dépôt et à la diffusion de documents scientifiques de niveau recherche, publiés ou non, émanant des établissements d'enseignement et de recherche français ou étrangers, des laboratoires publics ou privés. 


\section{Accepted Manuscript}

Title: 2-methoxyestradiol: New perspectives in colon carcinoma treatment

Authors: Michele Parks, Micol Tillhon, Francesca Donà, Ennio Prosperi, A. Ivana Scovassi

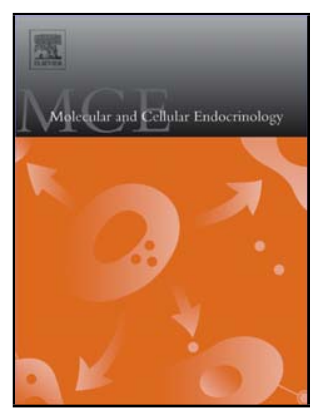

PII:

S0303-7207(10)00441-7

DOI: doi:10.1016/j.mce.2010.08.017

Reference: MCE 7629

To appear in: Molecular and Cellular Endocrinology

Received date: 31-3-2010

Revised date: $30-8-2010$

Accepted date:

$30-8-2010$

Please cite this article as: Parks, M., Tillhon, M., Donà, F., Prosperi, E., Scovassi, A.I., 2-methoxyestradiol: New perspectives in colon carcinoma treatment, Molecular and Cellular Endocrinology (2010), doi:10.1016/j.mce.2010.08.017

This is a PDF file of an unedited manuscript that has been accepted for publication. As a service to our customers we are providing this early version of the manuscript. The manuscript will undergo copyediting, typesetting, and review of the resulting proof before it is published in its final form. Please note that during the production process errors may be discovered which could affect the content, and all legal disclaimers that apply to the journal pertain. 


\section{2-methoxyestradiol: New perspectives in colon carcinoma treatment}

Michele Parks, Micol Tillhon, Francesca Donà, Ennio Prosperi, A. Ivana Scovassi*

Istituto di Genetica Molecolare CNR, Via Abbiategrasso 207, I-27100 Pavia, Italy

MP, MT, FD contributed equally to the work

*Corresponding author:
A. Ivana Scovassi
Istituto di Genetica Molecolare CNR
Via Abbiategrasso 207
27100 Pavia, Italy
Tel: +39-0382-546334
Fax: +39-0382-422286
E-mail: scovassi@igm.cnr.it 


\begin{abstract}
Colon carcinoma represents a major problem in oncology, since this type of cancer responds poorly to conventional chemotherapy. Many groups are actively involved in the search of new experimental strategies to bypass this problem. We investigated the effects of 2-methoxyestradiol (2-ME), which derives from the NADPH-dependent cytochrome $\mathrm{P} 450$ metabolism of $17 \beta$-estradiol. This compound has raised much interest in the past few decades for its inhibitory effects on the growth of cancer cells of different origin; however, little is known about its use on colon carcinoma-derived cell lines. In the present study, we investigated the effects of 2-ME on cell proliferation and cell cycle of two human colon carcinoma cell lines, namely HCT116 and SW613-B3. Our results showed a net anti-proliferative effect of 2-ME on both cell lines, which is accompanied by cell cycle arrest; moreover, we demonstrated that 2-ME is able to induce apoptosis as well as autophagy. This body of evidence points out that 2-ME could be considered as a promising tool against colon carcinoma.
\end{abstract}

Keywords

Apoptosis; autophagy; cell cycle; colon carcinoma cells; 2-methoxyestradiol 


\section{INTRODUCTION}

Resistance toward chemotherapy remains one of the principal obstacles to the effective treatment of cancer. Among the different therapeutic strategies adopted to beat cancer, a positive role of estrogens has been reported. Biological activity of estrogens is mainly mediated by their binding to estrogen receptors (ER) $-\alpha$ and $-\beta$, that belong to the steroid/thyroid hormone receptor superfamily of nuclear receptors. They are activated upon binding of the ligand, being able to interact with cis-regulatory elements of target genes either by the direct association to estrogen-response elements (EREs) or through the interaction with other DNA-bound transcription factors, such as activator protein 1 (AP-1) and stimulating protein-1 (SP-1) (Matthews and Gustafsson 2003).

The present research focuses on the use of 2-methoxyestradiol (2-ME) to block colon cancer cell proliferation. Once thought to be an inactive metabolite, 2-ME derives from the NADPH-dependent cytochrome P450 metabolism of $17 \beta$-estradiol and has been described to inhibit cancer proliferation. A pioneering study reported the ability of 2 ME to inhibit cell proliferation of a bovine brain-derived capillary endothelial cell line (Fotsis et al. 1994). Thereafter, a similar effect on various tumor cell lines was described (Pribluda et al. 2000; Qadan et al. 2001; Bu et al. 2002). 2-ME was found to inhibit tubulin polymerization by interacting at the colchicin-binding site and to disrupt microtubule dynamics (Kamath et al. 2006; Bhati et al. 2007). It is generally considered that low (nanomolar range) concentrations of 2-ME could be effective on cell proliferation, depending on cell types, while the anti-mitotic property requires micromolar concentrations.

Many studies have reported the ability of 2-ME to induce apoptosis in various human cancer cell lines, triggering both the extrinsic and intrinsic pathways (Mooberry 2003; Sutherland et al. 2007). 2-ME was also found to exert a strong anti-angiogenic effect (reviewed in Pribluda et al. 2000; Mooberry 2003; Dubei et al. 2009), possibly correlated to its ability to inhibit Hypoxia Induced Factor-1 (HIF-1) expression by altering microtubule assembly dynamics (Mabjeesh et al. 2003; Mooberry 2003). A recent proteomic survey has identified new mechanisms of action of 2-ME in pancreatic cells, involving glucocorticoid receptor and NF- $\mathrm{KB}$ (Basu and Haldar 2010). Taken together, the reported effects allow the identification of 2-ME as a promising anticancer drug.

Few studies have been conducted on the effect of 2-ME on colon carcinoma (Carothers et al. 2002; Zou et al. 2006), a type of cancer that responds poorly to therapies, and represents a major problem in clinical oncology. The present investigation aims at depicting the effects of 2-ME on cell proliferation, cell cycle, apoptosis and autophagy of two human colon carcinoma-derived cell lines: the highly tumorigenic HCT116 and the non-tumorigenic/drug-resistant, SW613-B3. Our results demonstrated that 2-ME exerts a strong anti-proliferative activity, promotes cell cycle arrest and induces apoptosis as well as autophagy. 


\section{MATERIALS AND METHODS}

\subsection{Cell culture and treatments}

Human colon carcinoma HCT116 and SW613-B3 cells, HeLa (from uterine cervix carcinoma), and $\mathrm{FO} 46$ normal fibroblasts were grown at $37^{\circ} \mathrm{C}$ under a $5 \% \mathrm{CO}_{2}$ atmosphere, in Dulbecco's modified Eagle's medium (DMEM), supplemented with $10 \%$ FBS, $0.1 \mathrm{mg} / \mathrm{ml}$ penicillin, $100 \mathrm{U} / \mathrm{ml}$ streptomycin, $2 \mathrm{mM}$ glutamine and $2 \%$ sodium pyruvate (all reagents were from Celbio, Milano, Italy). Twenty-four $\mathrm{h}$ after seeding, cells were treated for $24 \mathrm{~h}$ either with etoposide (Sigma Aldrich, Milano, Italy, stock solution: $50 \mathrm{mM}$ in DMSO) or 2-methoxyestradiol (2-ME, Sigma, stock solution: $10 \mathrm{mM}$ in DMSO), followed by $24-\mathrm{h}$ recovery in drug-free medium. Drug concentrations are specified for each assay. In most experiments, the final concentration of DMSO in culture medium was less than $0.2 \%(\mathrm{v} / \mathrm{v})$ and it did not have any effect on the activities tested in this study. Under some conditions, a fraction of 2-ME-treated cells tended to detach; this population was analyzed separately or in combination with attached cells, as specified for each assay.

\subsection{Morphological analysis}

For microscope observation, cells grown in $3.5-\mathrm{cm}$ diameter Petri dishes $\left(5 \times 10^{4} / \mathrm{ml}\right)$ were treated with $10 \mu \mathrm{M} 2-\mathrm{ME}$ for $24 \mathrm{~h}$, followed by 24-h recovery in drug-free medium. At the end of the treatment, cells were observed using an Olympus IX71 microscope equipped with a 10x objective and images were acquired with a digital

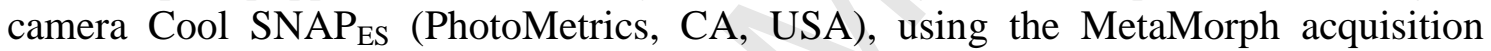
software; Adobe Photoshop 9.0.2 was used as elaborating software.

\subsection{Viability assays}

The effect of 2-ME on cell proliferation was evaluated by two different procedures (Giansanti et al. 2009): 1) the MTT metabolic viability assay, which measures mitochondrial activity, and 2) the measurement of the amount of DNA released from cells after alkaline lysis, that is proportional to the cell number. 1) MTT assay. Cells were seeded in 96-multiwell plates at a density of $10^{3} / 100 \mu \mathrm{l} /$ well. Twenty-four h later, cells were treated for $24 \mathrm{~h}$ with $1 \mu \mathrm{M}$ or $10 \mu \mathrm{M} 2-\mathrm{ME}$, followed by $24-\mathrm{h}$ recovery in drug-free medium. In addition to untreated controls, parallel samples were incubated under the same conditions with $0.1 \%$ DMSO to evaluate the possible effect of 2-ME solvent. At the end of the incubation, $20 \mu 1$ of CellTiter $96 \mathrm{AQ}_{\text {ueous }}$ One Solution Cell Proliferation Reagent (Promega Italia, Milano, Italy) were added to each well. The plates were then maintained for $4 \mathrm{~h}$ at $37^{\circ} \mathrm{C}$ and analyzed with a microplate reader (Gio.De Vita, Roma, Italy) at $492 \mathrm{~nm}$. Experiments were performed in quadruplicate and repeated three times. This procedure allows the evaluation of viability of the whole cell population. Data of treated are expressed in comparison to control samples \pm SD. 2) DNA release assay. Cells were seeded in 6-cm diameter Petri dishes at a density of $5 \times 10^{4}$ cells $/ \mathrm{ml}$ and, $24 \mathrm{~h}$ later, treated for $24 \mathrm{~h}$ with $10 \mu \mathrm{M} 2-\mathrm{ME}$, and further incubated for $24 \mathrm{~h}$ in drug-free medium. Untreated controls, and samples incubated under the same conditions with $0.1 \%$ DMSO were also considered. Detached cells were discarded, while attached cells were washed in PBS, trypsinized, centrifuged for $5 \mathrm{~min}$ at $1500 \mathrm{rpm}$ and lysed with $1 \mathrm{ml}$ of $0.1 \mathrm{M} \mathrm{NaOH}$; samples were accurately mixed and heated for $30 \mathrm{~min}$ at $50^{\circ} \mathrm{C}$, then allowed to reach room-temperature and kept at $4^{\circ} \mathrm{C}$ until the spectrophotometric analysis. The amount of released DNA, which is 
proportional to the number of cells, was measured as the absorbance at $260 \mathrm{~nm}$. Optical density of treated samples was compared to the values of control cells. Three independent experiments were carried out. Statistical analysis was performed and data are presented as mean \pm S.D.

\subsection{Clonogenic assay}

To evaluate colony-forming ability, $2.5 \times 10^{2}$ cells $/ \mathrm{ml}$ were seeded in 6 -cm diameter Petri dishes and, $24 \mathrm{~h}$ later, treated for $24 \mathrm{~h}$ with 2-ME. Given that this assay implies the administration of 2-ME to single cells, a low concentration, i.e. $5 \mu \mathrm{M}$ was used. After drug removal, attached cells were washed with PBS and further grown in complete medium for 10 days, to allow colony formation by surviving cells. Untreated controls and samples incubated with the vehicle $0.05 \%$ DMSO were set up in parallel. Colonies were then washed with PBS, fixed for 10 min with $100 \%$ methanol, and stained with Coomassie Blue (0.1\% Page Blue G-90, 50\% methanol and $7.4 \%$ acetic acid). Colonies with more than 50 cells were counted. The percentage of colonies formed aftertreatment relative to untreated cells was determined. Experiments were performed in duplicate and repeated three times.

\subsection{Flow cytometry}

Cells were seeded in $10-\mathrm{cm}$ diameter Petri dishes $\left(10^{6} / \mathrm{dish}\right)$, grown in complete medium for $24 \mathrm{~h}$ and treated with $10 \mu \mathrm{M} 2-\mathrm{ME}$ for $24 \mathrm{~h}$. After the treatment, detached cells was recovered and added to the attached cells once the latter were trypsinized. The whole cell sample was centrifuged for $5 \mathrm{~min}$ at $1500 \mathrm{rpm}$ at $4^{\circ} \mathrm{C}$ and resuspended with cold $0.9 \% \mathrm{NaCl}\left(10^{6}\right.$ cells $\left./ \mathrm{ml}\right)$; cold $100 \%$ ethanol was added to cell suspension to a final concentration of $70 \%$. Samples were then incubated for $30 \mathrm{~min}$ at room temperature with $30 \mu \mathrm{g} / \mathrm{ml}$ propidium iodide (Sigma) and $2 \mathrm{mg} / \mathrm{ml}$ RNase A (Sigma), kept overnight at $4^{\circ} \mathrm{C}$ and finally analyzed using a Coulter Epics XL II flow cytometer (Beckman Coulter, Milano, Italy). For each sample, $10^{4}$ cells were measured and data were analyzed. The fluorescence intensity was converted in histograms, and the percentage of cells in each phase of the cellular cycle was calculated with XL II software. The applied procedure allows the evaluation of cell cycle distribution of the whole cell population. Experiments were repeated three times.

\subsection{Western blotting}

HCT116 and SW613-B3 cells were treated for $24 \mathrm{~h}$ with $100 \mu \mathrm{M}$ 2-ME. Attached (A) and detached (D) cell populations were harvested separately. Protein expression was evaluated by Western blotting according to Donà et al. (2008). After running and transfer of proteins onto nitrocellulose, membranes were incubated overnight at $4^{\circ} \mathrm{C}$, or $3 \mathrm{~h}$ at room temperature, with MAbs against the following proteins: PARP-1 (C2-10 Alexis Biochemicals, Vinci-Biochem, Firenze, Italy, diluted 1:1000); cyclin A (Cy-A1 Sigma, diluted 1:500); cyclin B1 (GNS1 Santa Cruz Biotechnology, TebuBio, Magenta, Italy, diluted 1:1000); p53 (DO-1 Santa Cruz Biotechnology, diluted 1:2000); caspase-3 (31A1067 Alexis, diluted 1:250); $\gamma$-tubulin (GTU-88 Sigma, diluted 1:10000). In some experiments, polyclonal antibodies against the following proteins were used: cyclin D1 (Upstate Biotechnology, Prodotti Gianni, Italy, diluted 1:500); p21 (C-21, Santa Cruz Biotechnology, diluted 1:1000); cleaved caspase-8 (Asp391 Cell Signaling Technology, Celbio, diluted 1:1000); cleaved caspase-9 (Asp315 Cell Signaling Technology, diluted 1:1000). Then, HRP-conjugated anti-mouse or anti-rabbit secondary antibody (Jackson 
ImmunoResearch, Suffolk, UK, diluted 1:10000) was applied for $45 \mathrm{~min}$ at room temperature. All antibodies were diluted in TBS $(140 \mathrm{mM} \mathrm{NaCl}, 100 \mathrm{mM}$ Tris-HCl, $\mathrm{pH}$ 7.5), containing 5\% skim milk and $0.1 \%$ Tween-20. Visualization of immunoreactive bands was achieved using a chemiluminescent substrate (Immun-Star ${ }^{\mathrm{TM}}$ WesternC $^{\mathrm{TM}}$ Chemiluminescent Kit, Bio Rad Laboratories, Segrate, Italy). Three independent experiments were performed. Densitometric analysis of immunoreactive bands was achieved with BioRad Quantity One software.

\subsection{Internucleosomal DNA degradation}

For DNA ladder analysis, control and treated samples containing $2.5 \times 10^{6}$ cells were processed as described in Giansanti et al. (2009). HCT116 and SW613-B3 cells were treated for $24 \mathrm{~h}$ with $100 \mu \mathrm{M}$ 2-ME. Attached (A) and detached (D) cell populations were harvested separately. HeLa cells treated with $100 \mu \mathrm{M}$ etoposide for $24 \mathrm{~h}(\mathrm{E})$ or growth factor-deprived (long-term, LT) were used as positive DNA ladder control (Torriglia et al. 1999). Pictures were taken with a photographic digital camera Kodak DC290 (Rochester, NY, USA).

\subsection{Immunofluorescence experiments}

Cells were seeded on coverslips $\left(5 \times 10^{4}\right.$ cells $\left./ \mathrm{ml}\right)$ and treated $24 \mathrm{~h}$ later either with 10 $\mu \mathrm{M}$ 2-ME or RS2780 (kindly provided by Prof. R. Silvestri, University of Roma La Sapienza, Italy) for $24 \mathrm{~h}$. After treatment, attached cells were fixed with cold paraformaldehyde (2\% in PBS) for $20 \mathrm{~min}$ and then post-fixed overnight with $70 \%$ ethanol at $-20^{\circ} \mathrm{C}$. The day after, cells were permeabilized on ice with $0.1 \%$ Triton $\mathrm{X}-100$ in PBS, incubated for 30 min with PTN (PBS containing 10\% newborn calf serum and $0.1 \%$ Tween-20) and then for $1 \mathrm{~h}$ at room temperature with the polyclonal antibody to AIF (apoptosis inducing factor) (Cell Signaling Technology, diluted 1:50), the MAb to mtHSP70 (JG1 Alexis, diluted 1:50) or with the anti-phosphorylated-H3 (P-H3) polyclonal antibody (Ser10 Upstate, diluted 1:20) in PTN. After washes with PBS, cells were incubated for 1 hour at room temperature with rhodamine- or fluoresceinconjugated anti-mouse or anti-rabbit IgG secondary antibody (Jackson ImmunoResearch) and then stained for $10 \mathrm{~min}$ with $0.2 \mu \mathrm{g} / \mathrm{ml}$ Hoechst 33258 in PBS in the dark. Finally, coverslips were mounted on slides with Anti-fade solution (90\% glycerol, $20 \mathrm{mM}$ Tris- $\mathrm{HCl} \mathrm{pH} \mathrm{7.5,0.1 \%} \mathrm{DABCO} \mathrm{diluted} \mathrm{in} \mathrm{PBS).} \mathrm{Samples} \mathrm{were}$ analyzed using an Olympus IX71 microscope equipped with a 63x objective; images were acquired as described above. Three independent experiments were performed.

\subsection{Autophagy markers}

For the evaluation of autophagy, cells were treated with $100 \mu \mathrm{M} 2-\mathrm{ME}$ for $24 \mathrm{~h}$, stained with $1 \mu \mathrm{g} / \mathrm{ml}$ Acridine Orange (AO, Sigma) for $15 \mathrm{~min}$ at $37^{\circ} \mathrm{C}$, then observed with an Olympus BX51 microscope. Images were taken with an Olympus C4040 camera. The autophagic markers Beclin-1, Atg 5-12, LC3 were monitored by Western blot (as described in section 2.6) by using the "Autophagy antibody kit" (Cell Signaling) under manufacturer's conditions. In situ conversion of LC3 form I to form II was visualized by immunofluorescence with the following protocol: control and treated cells were fixed with cold paraformaldehyde (4\% in PBS) for $15 \mathrm{~min}$, washed with PBS and permeabilized with cold acetone for $5 \mathrm{~min}$. After washings with PBS, samples were incubated with bovine serum albumin (4\% in PBS) for 10 min and with the polyclonal 
antibody to LC3 (see the above kit, diluted 1:100) for $1 \mathrm{~h}$ at $37^{\circ} \mathrm{C}$. Samples were then processed as in section 2.8 and observed with the above described microscope. 


\section{RESULTS}

\subsection{2-ME treatment affects colon carcinoma cell viability}

After setting the experimental conditions using HeLa cells (Supplementary Fig. 1), we analyzed the effects of 2-ME on human colon carcinoma cell lines HCT116 and SW613-B3. As shown in Fig. 1A, HCT116 cells still attached to the plastic support after the $24 \mathrm{~h}$-treatment with $10 \mu \mathrm{M}$ 2-ME, were fewer, larger in size compared to control cells and with a rounded morphology; a fraction of cells tended to detach from the Petri dish. After the 24 -h recovery $(24 \mathrm{~h}+24 \mathrm{~h})$, the floating cell population increased notably, indicating a stronger and prolonged effect of the drug on this cell line. The other colon carcinoma cells, i.e. SW613-B3, after a 24-h treatment were larger in size compared to control cells and tended to detach, while after an additional 24 h-recovery, cells started to acquire the original cell morphology (Fig. 1B). The response of the two cell lines to 2-ME appeared to be similar, with a marked loss of cell adhesion; however, SW613-B3 cells were less affected during the recovery period and reverted to the starting phenotype.

Then, we addressed the impact of 2-ME on cell viability. Preliminary experiments revealed that the addition of DMSO, which is the vehicle of 2-ME, to cell culture did not affect cell viability. As revealed by MTT assay, the 24 h-treatment of HCT116 cells with $1 \mu \mathrm{M}$ 2-ME reduced cell viability to $65.2 \pm 0.01$ with respect to the untreated cells considered as 100 , and to $48.6 \pm 0.04$ after further recovery in drug-free medium (Fig. $1 \mathrm{C})$. This effect was more pronounced at the higher concentration of the drug $(10 \mu \mathrm{M})$, which caused a minimal residual viability of $2.2 \pm 0.03$ after 24 h-treatment and $11.1 \pm 0.01$ after further recovery (Fig. 1C). SW613-B3 cell viability was reduced only to $67.5 \pm 0.01$ at the end of the treatment with $1 \mu \mathrm{M} 2-\mathrm{ME}$ and to $74.9 \pm 0.01$ after recovery (Fig. 1D); even after the administration of $10 \mu \mathrm{M} 2-\mathrm{ME}$, the values were not increased (60.6 \pm 0.02 after 24 h-treatment and $82.5 \pm 0.09$ after additional 24 h-recovery) (Fig. 1D). On the whole, these results showed a dose-dependent and irreversible response of HCT116 cells to 2-ME treatment (as it occurs for HeLa cells, Supplementary Fig. 1); on the contrary, the effect of the drug on SW613-B3 cells was poor and reversible at both concentrations, thus supporting the general drug-resistant behavior of this cell line.

When evaluated by DNA release measurement, HCT116 cell proliferation was affected after the treatment with $1 \mu \mathrm{M} 2-\mathrm{ME}(82.6 \pm 0.08$ after 24 h-treatment and $64.3 \pm 0.22$ after further recovery); the effect increased with $10 \mu \mathrm{M} 2-\mathrm{ME}(41.5 \pm 0.08$ and $40.8 \pm 0.06$ after 24 h-treatment and further recovery, respectively) (Fig. 1E). On the contrary, $1 \mu \mathrm{M} 2$ ME did not impair SW613-B3 cell proliferation $(93.7 \% \pm 0.01$ and $87.3 \pm 0.03$ after $24 \mathrm{~h}-$ treatment and further recovery, respectively), while the $10 \mu \mathrm{M}$ concentration reduced proliferation to $69.2 \pm 0.05$ after $24 \mathrm{~h}$-treatment and $59.6 \pm 0.06$ after the additional recovery (Fig. 1F). Consistent with the results from the MTT assay described above, SW613-B3 cells resulted more resistant to 2-ME compared to HCT116 cells.

The inhibitory effect of 2-ME on cell proliferation of the two colon carcinoma cell lines was confirmed by data on the colony forming ability. Taking into account that the assay was applied to single cells, the treatment was performed with $5 \mu \mathrm{M} 2-\mathrm{ME}$ for $24 \mathrm{~h}$ followed by a further growth in fresh medium to allow colony formation (10 days). As illustrated in Supplementary Fig. 2, we observed that the ability of both cell lines to form colonies appeared greatly reduced as an effect of 2-ME. Quantitative data are reported in Fig. 1G, showing a residual ability to form colonies of $9.6 \%$ for HCT116 
and $14.9 \%$ for SW613-B3 cells; the clonogenic potential of the latter cell line appeared to be less affected than that of HCT116 cells.

\subsection{Effect of 2-ME on cell cycle}

To correlate the anti-proliferative effect of 2-ME with cell cycle disturbance, we analyzed cell cycle distribution by flow cytometry on both cell lines treated with $10 \mu \mathrm{M}$ 2-ME. As illustrated in Fig. 2, both 2-ME-treated cell lines showed a higher percentage of cells accumulated in the $\mathrm{G}_{2} / \mathrm{M}$ phase of cell cycle after $24 \mathrm{~h}$-treatment compared to control cells (63.6\% for HCT116, panel b; 49.4\% for SW613-B3, panel f). After further 24 h-recovery in drug-free medium, the HCT116 cell population (panel d) was no longer predominantly accumulated in the $\mathrm{G}_{2} / \mathrm{M}$ phase $(12.9 \%)$ and a $33.2 \%$ fraction of the population was characterized by cells containing an amount of DNA $<2 \mathrm{C}$, which is a typical marker of apoptotic cells $\left(\mathrm{A}_{0}\right.$ region). Also SW613-B3 cells showed a decreased percentage of cells blocked in $\mathrm{G}_{2} / \mathrm{M}(11.4 \%)$ and a concomitant increase in $\mathrm{G}_{1}(26.8 \%)$ and $\mathrm{S}(21.3 \%$ ) phases (panel h), thus suggesting that this cell line was able to re-enter cell cycle after drug removal. However, these cells also undergo apoptosis, as indicated by the $\mathrm{A}_{0}$ fraction accounting for $19.2 \%$ of cell population. Notably, cells with DNA content $>4 \mathrm{C}$ were present in both cell lines after treatment with 2-ME, possibly originating through an endoreduplication process; this would account for the cell population showing an increase in size when observed by microscopy (Ting et al. 2010).

\subsection{Analysis of cell cycle checkpoints}

To clarify whether the effects induced by 2-ME on cell cycle were attributable to an impaired progression through $\mathrm{G}_{2} / \mathrm{M}$ phase, the levels of cyclins $\mathrm{D} 1$, A, and B1 were analyzed by Western blotting. Cyclin D1 is active in $\mathrm{G}_{1}$ phase and is required for cell cycle $G_{1}$ transition; cyclin $A$ is necessary to $S$ phase progression and $S / G_{2}$ transition, and is degraded at entry in mitosis, while cyclin B1 increases from late $\mathrm{G}_{2}$ to metaphase, and is degraded in anaphase to allow mitotic exit.

Western blot analysis was performed on control cells (C) and on both the attached (A) and detached (D) fractions of cells treated with $100 \mu \mathrm{M}$ 2-ME for $24 \mathrm{~h}$ (Fig. 3A) followed by the quantitative evaluation of band intensity (Fig. 3B). Cyclin D1 levels decreased in both fractions of HCT116 treated cells (compare 1 a.u. of control cells with 0.2 for attached and 0.4 for the detached population). As shown in the same Figure, cyclin A levels remained unchanged. Cyclin B1 expression increased by 4- and 1.4times in the detached and attached fraction of 2-ME-treated HCT116 cells, respectively. This increase can be due to a lack of degradation of cyclin $\mathrm{B} 1$ and could be responsible for the accumulation of HCT116 cells at the transition between $\mathrm{G}_{2}$ phase and mitosis, which impairs the ability to conclude cell cycle. In fact, they became floating, possibly undergoing apoptosis.

In SW613-B3 cells, we observed that the levels of cyclin D1 and B1 slightly increased (1.4-times) in the attached fraction and decreased to 0.7 in the detached one; cyclin A remained unchanged in the attached fraction and resulted much lower in the detached one (0.2 a.u.). These data indicate that, after 2-ME treatment, attached SW613-B3 cells remained arrested in $\mathrm{G}_{2}$ phase, while detached cells were not able to progress through mitosis and, as a cause of this, probably underwent apoptosis, as suggested by the low levels of all cyclins analyzed.

To understand if the different status of p53 (wt for HCT116 and mutated for SW613-B3 cells) could influence the response to 2-ME, we evaluated the levels of p53 and of its 
target p21 by Western blotting (Fig. 3). The basal level of p53 appeared to be similar in both cell lines; in 2-ME-treated HCT116 cells, we found that p53 level was reduced to about $60 \%$ in both attached and detached fractions compared to control cells; the parallel decrement of p21 levels indicates that these proteins are functionally correlated. SW613-B3 cells showed a lower expression in p53 amount compared to control. Remarkably, p21 level increased by two-times in treated, $\mathrm{G}_{2}$-arrested, attached cells. The p53-independent modulation of p21 in p53-mutated cells could contribute to the cell cycle arrest in $\mathrm{G}_{2} / \mathrm{M}$ observed after 2-ME administration in SW613-B3 cells. In fact, as recently reviewed (Cazzalini et al. 2010), p21 not only mediates cell cycle $G_{1} / S$ transition but also plays a crucial role in the $\mathrm{G}_{2}$-phase checkpoint.

To further characterize the 2-ME-induced $\mathrm{G}_{2} / \mathrm{M}$ cell cycle arrest, we analyzed the expression of phosphorylated histone H3 (P-H3), which is a good marker of mitosis. As illustrated in Fig. 4, after the treatment with 2-ME, immunofluorescence experiments showed a 2- and 5-times increase of the amount of P-H3-positive HCT116 and SW613B3 cells, respectively (11.6\% and 53.5\%, compared to control cells: $6.2 \%$ and $11.8 \%$ ), indicating that 2-ME arrested HCT116 cells prevalently at $\mathrm{G}_{2} / \mathrm{M}$ transition, while SW613-B3 cells mainly accumulated during the final step of mitosis, in agreement with the data previously obtained by flow cytometry experiments.

\subsection{2-ME induces apoptosis in colon cancer cells}

In order to understand whether 2-ME is able to induce apoptosis in HCT116 and SW613-B3 cells, we analyzed several apoptotic markers, i.e. internucleosomal DNA fragmentation (by DNA ladder analysis), PARP-1 proteolysis and caspase-3, -8 and -9 activation (by Western blotting). This set of experiments was performed with $100 \mu \mathrm{M}$ 2-ME in order to increase the amount of detached cells as an effect of the treatment, being this population usually characterized by apoptotic features. To avoid the possible interference of DMSO, parallel samples containing the equivalent concentration of DMSO in the culture medium were processed; all the assays revealed no direct effect of the solvent on apoptotic parameters (not shown).

As a positive control of apoptotic DNA fragmentation, according to a standard protocol (Torriglia et al. 1999) we used HeLa cells either treated with $100 \mu \mathrm{M}$ etoposide (an inhibitor of DNA topoisomerase II which induces DNA double strand breaks and apoptosis) or growth factor-deprived. In fact, as illustrated in Fig. 5, HeLa cells treated with etoposide (E), or maintained in culture for 9 days (LT, long term) showed a clear DNA ladder. DNA analysis carried out on both attached (A) and detached (D) HeLa cell fractions obtained after $24 \mathrm{~h}$ treatment with $100 \mu \mathrm{M}$ 2-ME revealed the appearance of DNA ladder, thus demonstrating the ability of 2-ME to induce apoptosis. In the same experimental conditions, HCT116 cells also showed a clear DNA ladder in the detached fraction, while in SW613-B3 samples only a faint DNA degradation was visible. Accordingly, PARP-1 proteolysis, a hallmark of caspase-dependent apoptosis (Soldani and Scovassi 2002), occurred in etoposide (E) and 2-ME-treated HeLa cells, where a total conversion of PARP-1 from full-length $(113 \mathrm{kDa})$ to the $89 \mathrm{kDa}$ fragment was observed (Fig. 6). HCT116 cells also showed a complete PARP-1 degradation, while intact PARP-1 was still visible in SW613-B3 cells together with the cleaved fragment. The analysis of this parameter supported the observation that 2-ME is able to induce apoptosis in colon carcinoma cells.

We then investigated the event upstream PARP-1 proteolysis, i.e. caspase- 3 activation. Western blotting analysis revealed in etoposide-treated HeLa cells (E) as well as in the 
detached fractions of 2-ME-treated HeLa and HCT116 cells a nearly complete conversion of the $35 \mathrm{kDa}$ pro-caspase- 3 to the 17 and $12 \mathrm{kDa}$ active fragments. Caspase-3 activation also occurred in SW613-B3 cells, even if uncleaved caspase-3 was still detectable in the detached fraction (Fig. 6). These results suggest that in SW613-B3 cells, PARP-1 and caspase-3 conversion into proteolytic fragments requires a longer time to occur. This point should be further addressed by a time-course study.

Finally, we evaluated the caspase- 8 and -9 , which are activated during the extrinsic or intrinsic apoptotic pathway, respectively, and in turn regulate the activation of caspase3. Western blot analysis revealed the activation of caspase-8 in all 2-ME-treated cells, while the active form of caspase-9 was visible only in HeLa cells (Fig. 6). These results demonstrated that 2-ME was able to activate the extrinsic pathway in colon carcinoma cell lines. Lambert et al. (2004) demonstrated that 2-ME is capable of activating apoptosis in a caspase-independent manner. For this reason, we analyzed the localization of AIF (apoptosis-inducing factor) that translocates from the mitochondria to the nucleus under a caspase-independent paradigm of death; in parallel, we monitored the mitochondrial protein HSP70 (mtHSP70) by double immunofluorescence experiments. The applied procedure was recently developed in our laboratory to visualize AIF translocation in human cancer cells treated with the pyrazolecarboxamide RS2780 (Giansanti et al. 2009). As a positive control of the assay, we included in the experiment HeLa cells treated under conditions leading to AIF release (Giansanti et al. 2009). The results reported in Fig. 7C confirmed that the RS2780 induces a redistribution of mitochondria (as illustrated by the red labeling of the mitochondrial protein HSP70), together with the translocation of a pool of AIF to the nucleus (green fluorescence). On the contrary, the $24 \mathrm{~h}$-treatment with $10 \mu \mathrm{M}$ 2-ME caused an altered mitochondrial organization within the cells but AIF localization remained confined to mitochondria in both colon carcinoma cell lines (Fig. 7A, HCT116 cells; 7B, SW613B3 cells). Thus, under our experimental conditions, 2-ME did not activate the AIFdependent apoptotic pathway, even if an involvement of mitochondria (and by consequence, of the intrinsic pathway) in 2-ME-induced apoptosis cannot be excluded.

\subsection{2-ME induces autophagy}

Finally, we investigated the possible occurrence of autophagy in 2-ME-treated cells. This issue was addressed first by staining cells with Acridine Orange (AO), which enters acidic compartments like lysosomes, where it emits orange fluorescence that is suggestive of autophagy. We recorded this phenomenon in HeLa and SW613-B3 cells treated with 2-ME (upper part of Supplementary Fig. 3A and B, respectively). We further provided the in situ evidence of the conversion of LC3 (Light Chain 3), into the form LC3-II, that is a marker of the final step of autophagy (HeLa cells, Supplementary Fig. 3A, lower part). To go deeper into the finding that 2-ME could induce autophagy in our experimental conditions, we analyzed in details the LC3 pathway in SW613-B3 cells by evaluating crucial factors such as Beclin-1 and the complex Atg 5-12. Western blot analysis (Supplementary Fig. 3B, lower part) revealed that Beclin-1 increased (about 2-times) in 2-ME-treated SW613-B3 cells. In the same samples, we detected the Atg 5-12 complex as well as the conversion of the form I of LC3 into the form II (Supplementary Fig. 3B, lower part). These results provided the evidence that 2-ME could induce autophagy; more precisely, the process appeared to be regulated by Beclin-1, which, in turn, promotes the formation of the Atg complex responsible for the LC3 conversion into the form II. 


\section{Discussion}

It is widely known that colon carcinoma is extremely resistant to conventional chemotherapy (Majer et al. 2007); for this reason, many investigators are involved in the search of experimental strategies able to improve the efficacy of the treatments. In this respect, our laboratory has recently identified a pyrazolecarboxamide (Giansanti et al. 2009) and an arylthioindole (Giansanti et al. 2010) that proved to be efficient in inhibiting colon carcinoma cell proliferation.

In the present study we addressed the possible use of 2-ME to inhibit the proliferation of (and kill) two human colon carcinoma-derived cell lines, i.e. HCT116 and SW613-B3, which differ for a number of properties, including p53 status and tumorigenic potential (Table 1). In cells treated with 2-ME, we analyzed various parameters, including cell proliferation, cell cycle distribution and checkpoints, and apoptosis. Table 1 reports also the features of HeLa cells, which have been used in this study to set up the experimental conditions. The data obtained in this cell line were in agreement with those reported by Li et al. (2004) and enabled us to define the treatment protocol for colon carcinoma cell lines HCT116 and SW613-B3 (see Supplementary Fig. 1).

The results we obtained on colon carcinoma cell lines showed that 2-ME interferes with HCT116 cell viability in a dose-dependent/irreversible manner, while its effect on SW613-B3 is less potent and is reversible. This different impact of 2-ME could be explained by the high intrinsic resistance of the latter cell line to a panel of drugs (Donzelli et al. 1999; Bottone et al. 2003; Gorrini et al. 2003). However, we found that 2-ME has an inhibitory effect on cell viability of both colon carcinoma cells, thus suggesting that it could be a promising cytotoxic, anti-proliferative agent.

Given that 2-ME might produce undesired effects on normal cells, we addressed this issue by analyzing cell proliferation of human FO46 normal fibroblasts after a $24 \mathrm{~h}$ treatment with 1 and $10 \mu \mathrm{M}$ 2-ME and also after a further 24 h-recovery in drug-free medium. We did not observe a marked effect of 2-ME on cell viability (data not shown), in line with the original observation by Seegers et al. (1997), who demonstrated that normal human skin fibroblasts are not affected by 2-ME. Accordingly, the comparison between normal human fibroblasts and melanoma cell lines revealed that the former cells were not sensitive to the treatment (Dobos et al. 2004). The loss of effect of 2-ME on normal cells was also supported by the report by Van Zijl et al. (2008), showing that breast cancer MCF-7 cells are sensitive to 2-ME while their normal counterpart (i.e. MCF-12A cells) is not. Also the comparison between primary cultures of normal cells and cancerous ovarian epithelium revealed that only the latter cells are sensitive to 2-ME (Kato et al. 2008).

Next, we demonstrated that 2-ME displays a dose-dependent effect on cell cycle, leading to the accumulation of cells in $\mathrm{G}_{2} / \mathrm{M}$ characterized by the presence of phosphorylated-H3 histone. Cell cycle arrest was more evident in HCT116 cells, which were unable to re-enter cell cycle and showed upregulated levels of cyclin B1 (possibly due to the lack of its degradation) leading to cell death and detachement.

Although the effect of 2-ME on cell cycle was more pronounced for HCT116 cells, it occurred irrespectively of the p53 status, which is wt for HCT116 cells and mutated for SW613-B3 cells, where the accumulation in $\mathrm{G}_{2} / \mathrm{M}$ phase could be due to a p53independent upregulation of $\mathrm{p} 21$. The comparison between other cancer cell lines characterized by a different p53 behaviour will allow a better definition of the p53independent role of $\mathrm{p} 21$. The effects of $2-\mathrm{ME}$ on cell cycle we observed are in 
agreement with previous reports on other cancer cell lines (Kumar et al. 2001; Lin et al. 2001; Dobos et al. 2004; Li et al. 2004; Kar et al. 2008; Maran et al. 2008).

The above observations prompted us to investigate the possible pro-apoptotic effect of 2-ME. Remarkably, we found that 2-ME induces caspase-dependent apoptosis, as supported by the appearance of DNA ladder, PARP-1 proteolysis and caspase-3 activation. In particular, our data indicated an involvement of caspase- 8 and not of caspase-9 in the apoptotic cascade proteolysis, thus suggesting the activation of the extrinsic pathway. However, our evidence that mitochondria from 2-ME treated cells have an altered distribution, in line with the reported increase in mitochondria aggregating around the nuclear envelope (Thaver et al. 2009), could support an effect of the drug on mitochondria. In fact, it has been reported that 2-ME promotes the release of cytochrome $\mathrm{c}$ and the translocation of Bax protein to mitochondria in pancreatic cancer cells (Qanungo et al. 2002). These aspects could be evaluated in our experimental system. The effect of 2-ME on mitochondrial function and structure could be ascribed to the generation of oxidative stress and/or inhibition of SOD, with the consequent accumulation of superoxide (Huang et al. 2000; Wood et al. 2001; Fulda et al. 2010; Ting et al. 2010). The inhibitory effect of 2-ME on SOD has been exploited to potentiate the efficacy of photodynamic therapy (Golab et al. 2003).

The ability of 2-ME to induce apoptosis is a very important notion. In fact, given that drug resistance of cancer cells is often correlated with the evasion of apoptosis, a major goal in cancer research is to selectively increase the susceptibility of cancer cells to apoptosis-based strategies (Giansanti and Scovassi 2008). Previous studies have reported the ability of 2-ME to induce apoptosis in various human cancer cell lines, by triggering both the extrinsic (Pribluda et al. 2000; LaValle et al. 2003; Mooberry et al. 2003; Shimada et al. 2004; Kato et al. 2008; Thaver et al. 2009) and intrinsic pathway (Yue et al. 1997; Attalla et al. 1998, Schumacher and Neuhaus 2001; Bu et al. 2002; Mooberry 2003; Shimada et al. 2003; Gao et al. 2005; Zou et al. 2006; Fukui and Zhu 2009).

The activation of caspase-independent apoptosis by 2-ME has also been explored. Due to the generation of ROS by $2-\mathrm{ME}$ and the consequent impairment of mitochondrial dynamics, it has been shown that after 2-ME treatment, crucial apoptotic factors, including AIF, are released from mitochondria in rat sarcoma cells (Lambert et al. 2004) and in human ovarian epithelium (Kato et al. 2008). In our experimental conditions, we were unable to see AIF translocation in colon carcinoma cells treated with 2-ME.

A recent body of evidence correlates the effect of 2-ME to the induction of autophagy in different cell lines (Chen et al. 2008; Kirches and Warich-Kirches 2009; Lorin et al. 2009, 2010; Stander et al. 2010). We addressed this point by analyzing different factors involved in the autophagic pathway, that are Beclin-1, the complex Atg 5-12, and LC3. Glick et al. 2010). The procedures we applied allowed the detection of autophagic markers in 2-ME-treated cells, thus suggesting that not only apoptosis but also autophagy are induced by 2-ME. However, the correlation (if any) of these processes in our experimental system needs further investigation; special attention has to be paid to the possible protective effect of autophagy towards apoptosis, which could account for the drug resistance of some cancer cells (Dikic et al. 2010; Moreau et al. 2010).

The aim of our study was to elucidate the effects of 2-ME on human colon carcinoma cells, currently used in our laboratory as model system to test the efficacy of potential anti-cancer agents. A previous report (Carothers et al. 2002) described that 2-ME induces p53-mediated apoptosis in different human colon carcinoma cell lines, i.e. 
RKO, SW48 and HCT116. The latter cell line has been used also in the present study. In line with the above cited paper, we found that 2-ME induces apoptotic DNA ladder and PARP-1 proteolysis in HCT116 cells; in addition, we provided the evidence of the activation of caspase-3 and -8 and of the re-localization of mitochondria in 2-MEtreated cells. It has to be taken into account that our experimental design differed from that of Carothers et al. (2002), given that our analysis included the use of a second colon carcinoma cell line, i.e. the SW613-B3, which we found to be extremely drug resistant (Donzelli et al. 1999; Bottone et al. 2003; Gorrini et al. 2003). For this reason, the concentrations of 2-ME we used (1-100 $\mu \mathrm{M})$ were higher that those administered by Carothers et al. (2002), which reached a maximum of $2.5 \mu \mathrm{M}$. The rationale of our choice is supported by data on cell viability (not shown), demonstrating that we worked at sub-lethal concentrations of 2-ME. Of note, the highest 2-ME concentration used in the present study (i.e. $100 \mu \mathrm{M}$ ) is included in the range of human plasma exposure, achieved with the lowest (400 mg daily) and highest (2200 twice a day) administered doses, calculated on the basis of compound clearance (Sweeney et al. 2005; Dahut et al. 2006; Lakhani et al. 2007).

In conclusion, our observations indicating that 2-ME is able to block the growth of colon carcinoma cells and to kill them add new insights into the possible use of 2-ME against this type of cancer. 2-ME administered orally proved to be efficient in a clinical trial against solid tumors (Sweeney et al. 2005; Dahut et al. 2006). More recently, in vivo studies concluded that the administration of $2-\mathrm{ME}$ (Panzem ${ }^{\circledR}$ ) is a powerful tool for treating various types of cancers (http://clinicaltrials.gov/ct2/results?term=2methoxyestradiol). Of course, some problems correlated to the availability and metabolism of 2-ME exist, given that it is rapidly metabolized to inactive compounds. Technical improvement of 2-ME administration by nanocrystal dispersion was the object of recently set up clinical trials (Tevaarwerk et al. 2009; Harrison et al. 2010). In this respect, an active research aims at finding new methods of delivery, mainly based on the encapsulation of 2-ME (Wang et al. 2009; Du et al. 2010; Mueck and Seeger 2010). Interestingly, the 2-ME analog ENMD-1198 is currently administered orally to oncology patients in a phase I clinical trial (Pasquier et al. 2010; Zhou et al. 2010).

Despite the encouraging results about the beneficial effect in 2-ME in contrasting cancer, the mechanisms at the basis of its pharmacological activity are not fully elucidated. Further work is needed to dissect the pathways induced by 2-ME, and to exploit the correlation between apoptosis and autophagy.

\section{Acknowledgements}

MT is a PhD student from University of Pavia (Dottorato in Scienze genetiche e molecolari) supported by the AIRC grant 5126; FD is supported by Fondazione Cariplo (grant \# 2006-0734). We are indebted to Prof. L. Moro (Università Avogadro, Novara, Italy), and Dr. P. Lombardi (Naxospharma, Novate Milanese, Italy) for helpful discussion. We thank Dr. G. Mazzini and Dr. V. Giansanti (IGM-CNR, Pavia, Italy) for help in autophagy experiments. We kindly acknowledge the reviewers for stimulating us to improve the manuscript. 


\section{References}

Attalla, H., Westberg, J.A., Andersson, L.C., Adlercreutz, H., Mäkelä, T.P. 1998. 2Methoxyestradiol-Induced Phosphorylation of Bcl-2: Uncoupling from JNK/SAPK Activation. Biochem. Biophys. Res. Commun. 247, 616-619.

Basu, A., Haldar S. 2009. 2-Methoxyestradiol mediated signaling network in pancreatic cancer. Front. Biosci. 14, 2170-2180.

Bhati, R., Gökmen-Polar, Y., Sledge, G.W., Fan, C., Nakshatri, H., Ketelsen, D., Borchers, C.H., Dial, M.J., Patterson, C., Klauber-DeMore, N. $2007.2-$ methoxyestradiol inhibits the anaphase-promoting complex and protein translation in human breast cancer cells. Cancer Res. 67, 702-708.

Bottone, M.G., Soldani, C., Tognon, G., Gorrini, C., Lazzè, M.C., Brison, O., Ciomei, M., Pellicciari, C., Scovassi, A.I. 2003. Multiple effects of paclitaxel are modulated by a high c-myc amplification level. Exp. Cell Res. 15, 49-59.

Bu, S., Blaukat, A., Fu, X., Heldin, N.E., Landström, M. 2002. Mechanisms for 2methoxyestradiol-induced apoptosis of prostate cancer cells. FEBS Lett. 531, 141151.

Carothers, A.M., Hughes, S.A., Ortega, D., Bertagnolli, M.M. 2002. 2Methoxyestradiol induces p53-associated apoptosis of colorectal cancer cells. Cancer Lett. 187, 77-86.

Cazzalini, O., Scovassi, A.I., Savio, M., Stivala, L.A., Prosperi, E. 2010. Multiple roles of the cell cycle inhibitor p21(CDKN1A) in the DNA damage response. Mutat Res. 704, 12-20.

Chen, Y., McMillan-Ward, E., Kong, J., Israels, S.J., Gibson, S.B. 2008. Oxidative stress induces autophagic cell death independent of apoptosis in transformed and cancer cells. Cell Death Differ. 15, 171-182.

Dahut, W.L., Lakhani, N.J., Gulley, J.L., Arlen, P.M., Kohn, E.C., Kotz, H., McNally, D., Parr, A., Nguyen, D., Yang, S.X., Steinberg, S.M., Venitz, J., Sparreboom, A., Figg, W.D. 2006. Phase I clinical trial of oral 2-methoxyestradiol, an antiangiogenic and apoptotic agent, in patients with solid tumors. Cancer Biol. Ther. 5, 22-27.

Dikic, I., Johansen, T., Kirkin, V. 2010. Selective autophagy in cancer development and therapy. Cancer Res. 70, 3431-3434.

Dobos, J., Tímár, J., Bocsi, J., Burián, Z., Nagy, K., Barna, G., Peták, I., Ladányi, A. 2004. In vitro and in vivo antitumor effect of 2-methoxyestradiol on human melanoma. Int. J. Cancer 112, 771-776.

Donà, F., Prosperi, E., Savio, M., Coppa, T., Scovassi, A.I., Mondello, C. 2008. Loss of histone $\mathrm{H} 2 \mathrm{AX}$ increases sensitivity of immortalized mouse fibroblasts to the topoisomerase II inhibitor etoposide. Int. J. Oncol. 33, 613-622.

Donzelli, M., Bernardi, R., Negri, C., Prosperi, E., Padovan, L., Lavialle, C., Brison, O., Scovassi, A.I. 1999. Apoptosis-prone phenotype of human colon carcinoma cells with a high level amplification of the c-myc gene. Oncogene 18, 439-448.

Du, B., Li, Y., Li, X., A, Y., Chen, C., Zhang, Z. 2010. Preparation, characterization and in vivo evaluation of 2-methoxyestradiol-loaded liposomes. Int. J. Pharm. 384, 140147.

Dubey, R.K., Jackson, E.K. 2009. Potential vascular actions of 2-methoxyestradiol. Trends Endocrinol. Metab. 20, 374-379. 
Fotsis, T., Zhang, Y., Pepper, M.S., Adlercreutz, H., Montesano, R., Nawroth, P.P., Schweigerer, L. 1994. The endogenous oestrogen metabolite 2-methoxyestradiol inhibits angiogenesis and suppresses tumour growth. Nature 368, 237-239.

Fulda, S., Galluzzi, L., Kroemer, G. 2010. Targeting mitochondria for cancer therapy. Nat. Rev. Drug Discov. 9, 447-464.

Fukui, M. and Zhu, B.T. 2009. Mechanism of 2-Methoxyestradiol-induced apoptosis and growth arrest in human breast cancer cells. Mol. Carcinog. 48, 66-78.

Gao, N., Rahmani, M., Dent, P., Grant, S. 2005. 2-Methoxyestradiol-induced apoptosis in human leukemia cells proceeds through a reactive oxygen species and Aktdependent process. Oncogene 24, 3797-3809.

Giansanti, V. and Scovassi, A.I. 2008. Apoptosis and cancer. In: Mondello, C. (ed.), Multiple pathways in cancer development. Transworld Research Network. Kerala, India, pp. 135-147.

Giansanti, V., Camboni, T., Piscitelli, F., Prosperi, E., La Regina, G., Lazzè, M.C., Santin, G., Silvestri, R., Scovassi, A.I. 2009. Study of the effects of a new pyrazolecarboxamide: Changes in mitochondria and induction of apoptosis. Int. J. Biochem. Cell Biol. 41, 1890-1898.

Giansanti V., Piscitelli F., Camboni T., Prosperi E., La Regina G., Parks M., Silvestri S., Scovassi A.I. 2010. Arylthioindoles: promising compounds against cancer cell proliferation. Oncol. Lett. 1, 109-112.

Glick, D., Barth, S., Macleod, K.F. 2010. Autophagy: cellular and molecular mechanisms. J. Pathol. 221, 3-12.

Golab, J., Nowis, D., Skrzycki, M., Czeczot, H., Baranczyk-Kuzma, A., Wilczynski, G.M., Makowski, M., Mroz, P., Kozar, K., Kaminski, R., Salili, A., Kopec', M., Grzela, T., Jakobisiak, M. 2003. Antitumor effects of photodynamic therapy are potentiated by 2 -methoxyestradiol. A superoxide dismutase inhibitor. J. Biol. Chem. 278, 407-414.

Gorrini, C., Donzelli, M., Torriglia, A., Supino, R., Brison, O., Bernardi, R., Negri, C., Denegri, M., Counis, M.F., Ranzani, G.N., Scovassi, A.I. 2003. Effect of apoptogenic stimuli on colon carcinoma cell lines with a different c-myc expression level. Int. J. Mol. Med. 11, 737-742.

Harrison, M.R., Hahn, N.M., Pili, R., Oh, W.K., Hammers, H., Sweeney, C., Kim, K., Perlman, S., Arnott, J., Sidor, C., Wilding, G., Liu, G. 2010. A phase II study of 2methoxyestradiol (2ME2) NanoCrystal(R) dispersion (NCD) in patients with taxane-refractory, metastatic castrate-resistant prostate cancer (CRPC). Invest. New Drugs, doi: 10.1007/s10637-010-9455-x.

Huang, P., Feng, L., Oldham, E.A., Keating, M.J., Plunkett, W. 2000. Superoxide dismutase as a target for the selective killing of cancer cells. Nature 407, 390-395.

Kamath, K., Okouneva, T., Larson, G., Panda, D., Wilson, L., Jordan, M.A. 2006. $2-$ Methoxyestradiol suppresses microtubule dynamics and arrests mitosis without depolymerizing microtubules. Mol. Cancer. Ther. 5, 2225-2233.

Kar, S., Wang, M., Carr, B.I. 2008. 2-Methoxyestradiol inhibits hepatocellular carcinoma cell growth by inhibiting Cdc25 and inducing cell cycle arrest and apoptosis. Cancer Chemother. Pharmacol. 62, 831-840.

Kato, S., Sadarangani, A., Lange, S., Delpiano, A.M., Vargas, M., Brañes, J., Carvajal, J., Lipkowitz, S., Owen, G.I., Cuello, M.A. 2008. 2-Methoxyestradiol mediates apoptosis through caspase-dependent and independent mechanisms in ovarian cancer cells but not in normal counterparts. Reprod. Sci. 15, 878-894. 
Kirches, E., Warich-Kirches, M. 2009. 2-methoxyestradiol as a potential cytostatic drug in gliomas? Anticancer Agents Med. Chem. 9, 55-65.

Kumar, A.P., Garcia, G.E., Slaga, T.J. 2001. 2-Methoxyestradiol blocks cell-cycle progression at $\mathrm{G} 2 / \mathrm{M}$ phase and inhibits growth of human prostate cancer cells. Mol. Carcinog. 31, 111-124.

Lakhani, N.J., Sparreboom, A., Xu, X., Veenstra, T.D., Venitz, J., Dahut, W.L., Figg, W.D. 2007. Characterization of in vitro and in vivo metabolic pathways of the investigational anticancer agent, 2-methoxyestradiol. J. Pharm. Sci. 96, 1821-1831.

Lambert, C., Apel, K., Biesalski, H.K., Frank, J. 2004. 2-Methoxyestradiol induces caspase-independent, mitochondria-centered apoptosis in DS-sarcoma cells. Int. J. Cancer. 108, 493-501.

LaVallee, T.M., Zhan, X.H., Johnson, M.S., Herbstritt, C.J., Swartz, G., Williams, M.S., Hembrough, W.A., Green, S.J., Pribluda, V.S. 2003. 2-Methoxyestradiol upregulates death receptor 5 and induces apoptosis through activation of the extrinsic pathway. Cancer Res. 63, 468-475.

Li, L., Bu, S., Bäckström, T., Landström, M., Ulmsten, U., Fu, X. 2004. Induction of apoptosis and G2/M arrest by 2-Methoxyestradiol in human cervical cancer HeLaS3 cells. Anticancer Res. 24, 873-880.

Lin, H.L., Liu, T.Y., Wu, C.W., Chi, C.W. 2001. 2-Methoxyestradiol-induced caspase-3 activation and apoptosis occurs through G2/M arrest dependent and independent pathways in gastric carcinoma cells. Cancer 92, 500-509.

Lorin, S., Borges, A., Ribeiro Dos Santos, L., Souquère, S., Pierron, G., Ryan, K.M., Codogno, P., Djavaheri-Mergny, M. 2009. c-Jun NH2-terminal kinase activation is essential for DRAM-dependent induction of autophagy and apoptosis in 2methoxyestradiol-treated Ewing sarcoma cells. Cancer Res. 69, 6924-6931.

Lorin, S., Pierron, G., Ryan, K.M., Codogno, P., Djavaheri-Mergny, M. 2010. Evidence for the interplay between JNK and p53-DRAM signalling pathways in the regulation of autophagy. Autophagy 6, 153-154.

Mabjeesh, N.J., Escuin, D., LaVallee, T.M., Pribluda, V.S., Swartz, G.M., Johnson, M.S., Willard, M.T., Zhong, H., Simons, J.W., Giannakakou, P. 2003. 2ME2 inhibits tumor growth and angiogenesis by disrupting microtubules and dysregulating HIF. Cancer Cell 3, 363-375.

Majer, M., Akerley, W., Kuwada, S.K. 2007. Oncologists' current opinion on the treatment of colon carcinoma. Anticancer Agents Med. Chem. 7, 492-503.

Maran, A., Shogren, K.L., Benedikt, M., Sarkar, G., Turner, R.T., Yaszemski, M.J. 2008. 2-methoxyestradiol-induced cell death in osteosarcoma cells is preceded by cell cycle arrest. J. Cell. Biochem. 104, 1937-1945.

Matthews, J., Gustafsson, J.A. 2003. Estrogen signaling: a subtle balance between ER alpha and ER beta. Mol. Interv. 5, 281-292.

Mooberry, S.L. 2003. Mechanism of action of 2-methoxyestradiol: new developments. Drug Resist. Updat. 6, 355-361.

Moreau, K., Luo, S., Rubinsztein, D.C. 2010. Cytoprotective roles for autophagy. Curr. Opin. Cell Biol. 22, 206-211.

Mueck, A.O., Seeger, H. 2010. 2-Methoxyestradiol-Biology and mechanism of action. Steroids, doi: 10.1016/j.steroids.2010.02.016.

Pasquier, E., Sinnappan, S., Munoz, M.A., Kavallaris, M. 2010. ENMD-1198, a new analogue of 2-methoxyestradiol, displays both antiangiogenic and vasculardisrupting properties. Mol. Cancer Ther. 9, 1408-1418. 
Pribluda, V.S., Gubish, E.R., LaVallee, T.M., Treston, A., Swartz, G.M., Green, S.J. 2000. 2-Methoxyestradiol: An endogenous antiangiogenic and antiproliferative drug candidate. Cancer Metastasis Rev. 19, 173-179.

Qanungo, S., Basu, A., Das, M., Haldar, S. 2002. 2-Methoxyestradiol induces mitochondria dependent apoptotic signaling in pancreatic cancer cells. Oncogene 21, 4149-4157.

Qadan, L.R., Perez-Stable, C.M., Anderson, C., D’Ippolito, G., Herron, A., Howard, G.A., Roos, B.A. 2001. 2-Methoxyestradiol induces G2/M arrest and apoptosis in prostate cancer. Biochem. Biophys. Res. Commun. 285, 1259-1266.

Schumacher, G. and Neuhaus, P. 2001. The physiological estrogen metabolite 2methoxyestradiol reduces tumor growth and induces apoptosis in human solid tumors. J. Cancer Res. Clin. Oncol. 127, 405-410.

Seegers, J.C., Lottering, M.L., Grobler, C.J.S., Papendorp, D.H.V., Habbersett, R.C., Shou, Y., Lehnert, B.E. 1997. The mammalian metabolite, 2-Methoxyestradiol, affects P53 levels and apoptosis induction in transformed cells but not in normal cells. J. Steroid. Biochem. Mol. Biol. 62, 253-267.

Shimada, K., Nakamura, M., Ishida, E., Kishi, M., Konishi, N. 2003. Roles of p38- and c-jun NH2-terminal kinase-mediated pathways in 2-methoxyestradiol-induced p53 induction and apoptosis. Carcinogenesis 24, 1067-1075.

Shimada, K., Nakamura, M., Ishida, E., Kishi, M., Matsuyoshi, S., Konishi, N. 2004. The molecular mechanism of sensitization to Fas-mediated apoptosis by 2methoxyestradiol in PC3 prostate cancer cells. Mol. Carcinog. 39, 1-9.

Soldani C. and Scovassi A.I. 2002. Poly(ADP-ribose) polymerase-1 cleavage during apoptosis: An update. Apoptosis 7, 321-328.

Stander, B.A., Marais, S., Vorster, C.J., Joubert, A.M. 2010. In vitro effects of 2methoxyestradiol on morphology, cell cycle progression, cell death and gene expression changes in the tumorigenic MCF-7 breast epithelial cell line. J. Steroid Biochem. Mol. Biol. 119, 149-160.

Sutherland, T.E., Anderson, R.L., Hughes, R.A., Altmann, E., Schuliga, M., Ziogas, J., Stewart, A.G. 2007. 2-Methoxyestradiol--a unique blend of activities generating a new class of anti-tumour/anti-inflammatory agents. Drug Discov. Today 12, 577584.

Sweeney, C., Liu, G., Yiannoutsos, C., Kolesar, J., Horvath, D., Staab, M.J., Fife, K., Armstrong, V., Treston, A., Sidor, C., Wilding, G. 2005. A Phase II multicenter, randomized, double-blind, safety trial assessing the pharmacokinetics, pharmacodynamics, and efficacy of oral 2-Methoxyestradiol capsules in hormonerefractory prostate cancer. Clin. Cancer. Res. 11, 6625-6633.

Tevaarwerk, A.J., Holen, K.D., Alberti, D.B., Sidor, C., Arnott, J., Quon, C., Wilding, G., Liu, G. 2009. Phase I trial of 2-Methoxyestradiol nanocrystal dispersion in advanced solid malignancies. Clin. Cancer. Res. 15, 1460-1465.

Thaver, V., Lottering, M.L., Papendorp, D.V., Joubert, A. 2009. In vitro effects of 2methoxyestradiol on cell numbers, morphology, cell cycle progression, and apoptosis induction in oesophageal carcinoma cells. Cell. Biochem. Funct. 27, 205210.

Ting, C.M., Lee, Y.M., Wong, C.K., Wong, A.S., Lung, H.L., Lung, M.L., Lo, K.W., Wong, R.N., Mak, N.K. 2010. 2-Methoxyestradiol induces endoreduplication through the induction of mitochondrial oxidative stress and the activation of MAPK signaling pathways. Biochem. Pharmacol. 79, 825-841. 
Torriglia A., Negri C., Chaudun E., Prosperi E., Courtois Y, Counis M.F., Scovassi A.I. 1999. Differential involvement of DNase II in HeLa cell apoptosis induced by etoposide and long term culture. Cell Death Differ. 6, 234-244.

Van Zijl, C., Lottering, M.L., Steffens, F., Joubert, A. 2008. In vitro effects of 2methoxyestradiol on MCF-12A and MCF-7 cell growth, morphology and mitotic spindle formation. Cell Biochem. Funct. 26, 632-642.

Wang, S.H., Shi, X., Chen, X., Baker, J.R. 2009. Therapeutic efficacy of 2Methoxyestradiol microcrystals encapsulated within polyelectrolyte multilayers. Macromol. Biosci. 9, 429-436.

Wood, L., Leese, M.R., Leblond, B., Woo, L.W., Ganeshapillai, D., Purohit, A., Reed, M.J., Potter, B.V., Packham, G. 2001. Inhibition of superoxide dismutase by 2methoxyoestradiol analogues and oestrogen derivatives: structure-activity relationships. Anticancer Drug Des. 16, 209-215.

Yue, T.L., Wang, X., Louden, C.S., Gupta, S., Pullarisetti, K., Gu, J.L., Hart, T.K., Lysko, P.G., Feuerstein, G.Z. 1997. 2-Methoxyestradiol, an endogenous estrogen metabolite, induces apoptosis in endothelial cells and inhibits angiogenesis: possible role for stress-activated protein kinase signaling pathway and Fas expression. Mol. Pharmacol. 51, 951-962.

Zhou, Q., Gustafson, D., Nallapareddy, S., Diab, S., Leong, S., Lewis, K., Gore, L., Messersmith, W.A., Treston, A.M., Eckhardt, S.G., Sidor, C., Camidge, D.R. 2010. A phase I dose-escalation, safety and pharmacokinetic study of the 2methoxyestradiol analog ENMD-1198 administered orally to patients with advanced cancer. Invest. New Drugs, doi: 10.1007/s10637-009-9383-9.

Zou, H.C., Adachi, M., Imai, K., Hareyama, M., Yoshioka, K., Zhao, S., Shinomura, Y. 2006. 2-Methoxyestradiol, an endogenous mammalian metabolite, radiosensitizes colon carcinoma cells through c-Jun NH2-terminal kinase activation. Clin. Cancer. Res. 12, 6532-6539. 


\section{LEGENDS TO FIGURES}

Fig. 1. Effect of 2-ME on cell morphology, proliferation and colony forming ability of colon carcinoma HCT116 and SW613-B3 cells. Cells were treated with $10 \mu \mathrm{M} 2-\mathrm{ME}$ for $24 \mathrm{~h}$, followed by a $24 \mathrm{~h}$-recovery in drug-free medium $(24 \mathrm{~h}+24 \mathrm{~h})$. (A,B) Microscopic observation of HCT116 and SW613-B3 cells, respectively. Bar $=50 \mu \mathrm{m}$. (C,D) Cell viability evaluated by MTT assay that measures metabolic mitochondrial activity of HCT116 and SW613-B3 cells, respectively. Cells were harvested at the end of the $24 \mathrm{~h}$-treatment with $10 \mu \mathrm{M}$ 2-ME (white columns) and after a further $24 \mathrm{~h}$ recovery in drug-free medium (grey columns). Data are expressed as percentage of treated cells compared to control cells. Standard deviation (S.D.) was calculated and since it ranged between 0.01 and 0.09 , it was not visualizable within the graph. (E,F) Cell proliferation measured by an assay based on DNA release from HCT116 and SW613-B3 cells, respectively. Cells were harvested at the end of the 24 h-treatment with $10 \mu \mathrm{M}$ 2-ME (white columns) and after a further $24 \mathrm{~h}$-recovery in drug-free medium (grey columns). Data are expressed as percentage of treated cells compared to control cells. S.D. was calculated and since it ranged between 0.01 and 0.22 , it was not visualizable within the graph. $(\mathrm{G})$ Colony forming ability evaluated on cells treated with $5 \mu \mathrm{M}$ for $24 \mathrm{~h}$ and further grown for 10 days in drug-free medium.

Fig. 2. Effect of 2-ME on cell cycle. Flow cytometry was performed on cells harvested after a 24 h-treatment with $10 \mu \mathrm{M} 2-\mathrm{ME}$ and after a further 24 h-recovery in drug-free medium. The sample includes both the attached and detached cell populations. The distribution of HCT116 and SW613-B3 cells in the various cycle phases $\left(G_{1}, S, G_{2} / M\right)$ was calculated as described in Materials and Methods. $\mathrm{A}_{0}$ region defines cells with DNA content $<2 \mathrm{C}$; polyploid cells show DNA content $>4 \mathrm{C}$. A typical result out of three is shown.

Fig. 3. Analysis of cell cycle checkpoints. (A) Western blot analysis of cyclins D1, A, B1, p53 and p21 was performed on protein extracts from control (C) and 2-ME-treated HCT116 and SW613-B3 cells. Attached (A) and detached (D) cell fractions were analyzed separately. Loading control was checked by $\gamma$-tubulin level. A representative result out of three is shown. Antibodies are described in Materials and Methods. (B) The expression level of the various proteins analyzed by Western blots shown in panel A was quantified by measuring band intensity by BioRad Quantity One software. For each band, the expression ratio with the relative tubulin intensity was calculated. Densitometric analysis of immunoreactive bands was expressed by considering control cells (C) as 1.0 arbitrary unit (a.u.). Sample A corresponds to attached cells; sample D to the detached population.

Fig. 4. Labeling of mitotic cells by phosphorylated histone $\mathrm{H} 3$ (P-H3). Immunofluorescence analysis was performed on control and 2-ME-treated HCT116 and SW613-B3 cells according to the procedure described in Materials and Methods. Bar = $50 \mu \mathrm{m}$.

Fig. 5. Internucleosomal DNA fragmentation (DNA ladder) in HCT116 and SW613-B3 cells. DNA was extracted from attached (A) and detached (D) cell fractions harvested separately after a 24 h-treatment with $100 \mu \mathrm{M}$ 2-ME. Positive controls of apoptosis: 
HeLa cells treated for $24 \mathrm{~h}$ with $100 \mu \mathrm{M}$ etoposide (E) or growth factor-deprived (longterm, LT). M: DNA molecular marker. Gel electrophoresis was detailed in Materials and Methods. A representative experiment out of three is shown.

Fig. 6. Proteolysis of PARP-1, caspase-3, -8 and -9. Protein extracts were prepared from control HeLa, HCT116 and SW613-B3 cells (C) and samples treated for $24 \mathrm{~h}$ with 100 $\mu \mathrm{M}$ 2-ME; attached (A) and detached (D) fractions were processed separately. HeLa cells treated with $100 \mu \mathrm{M}$ etoposide for $24 \mathrm{~h}$ (E) were used as positive control for apoptotic cells. Loading control was checked by $\gamma$-tubulin level. At least three independent experiments were carried out according to the procedure reported in Materials and Methods.

Fig. 7. Distribution of mitochondria and localization of AIF. (A,B) Double immunofluorescence experiments of control cells and treated with $10 \mu \mathrm{M} 2-\mathrm{ME}$ for $24 \mathrm{~h}$ HCT116 (A) and SW613-B3 (B) cells. (C) HeLa cells treated with $10 \mu \mathrm{M}$ RS2780 for $24 \mathrm{~h}$. Blue fluorescence: staining with Hoechst 33258; green fluorescence: AIF protein; red fluorescence: mtHSP70; yellow fluorescence: merge. Details of the immunofluorescence procedure are reported in Materials and Methods and in Giansanti et al. (2009). Bar $=50 \mu \mathrm{m}$. 
Table 1. Principal features of HCT116, SW613-B3 and HeLa cell lines.

\begin{tabular}{|l|l|l|l|l|}
\hline Cell line & Origin & $p 53$ & $\begin{array}{l}\text { Tumorigenic } \\
\text { potential }\end{array}$ & MMR \\
\hline HCT116 & $\begin{array}{l}\text { Colorectal } \\
\text { cancer }\end{array}$ & $\mathrm{wt}$ & + & Deficient \\
\hline SW613-B3 & $\begin{array}{l}\text { Colon } \\
\text { carcinoma }\end{array}$ & Mutated (codon 273) & - & Proficient \\
\hline HeLa & Uterine cervix & Inactive & + & Proficient \\
\hline
\end{tabular}



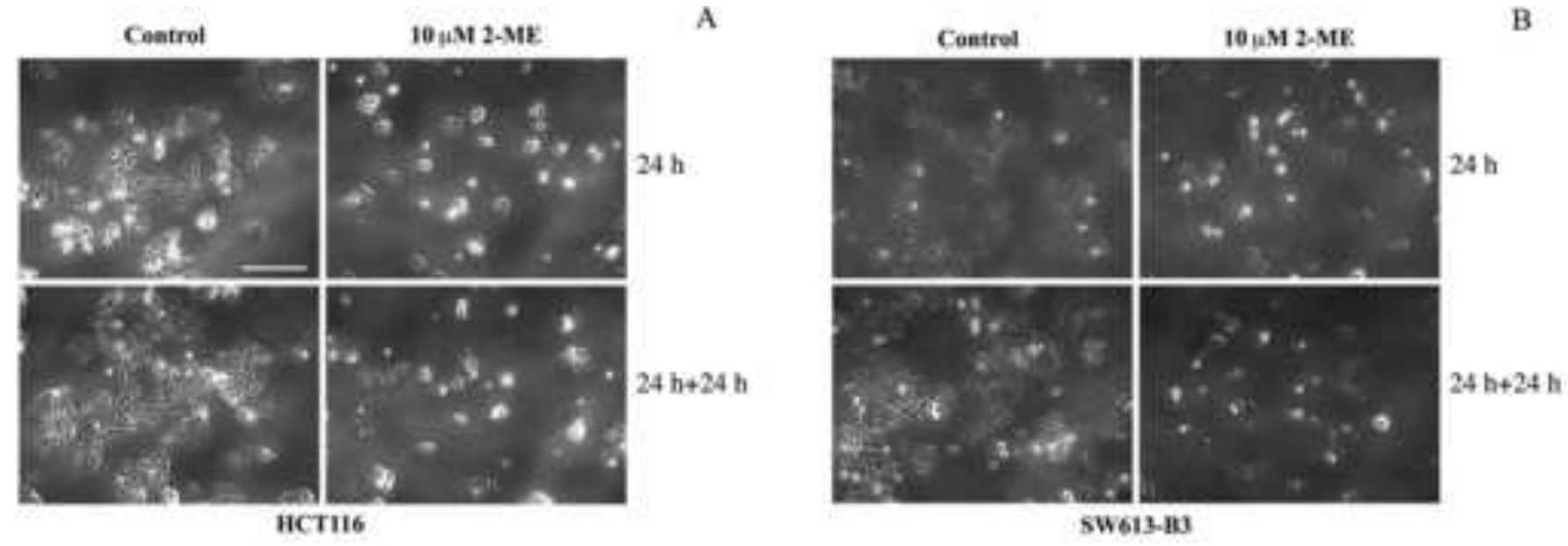

C
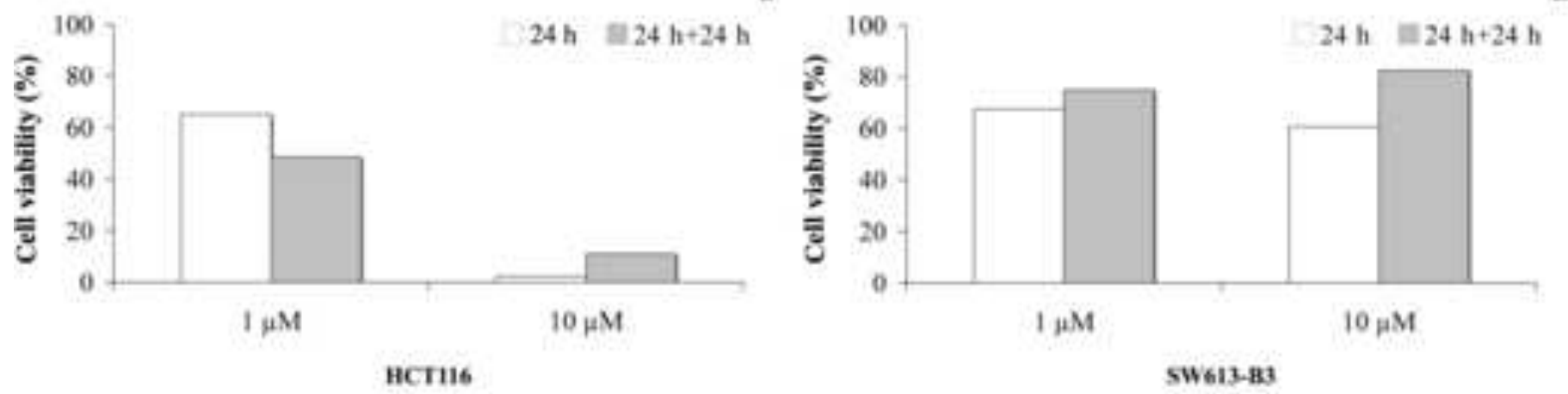

E F
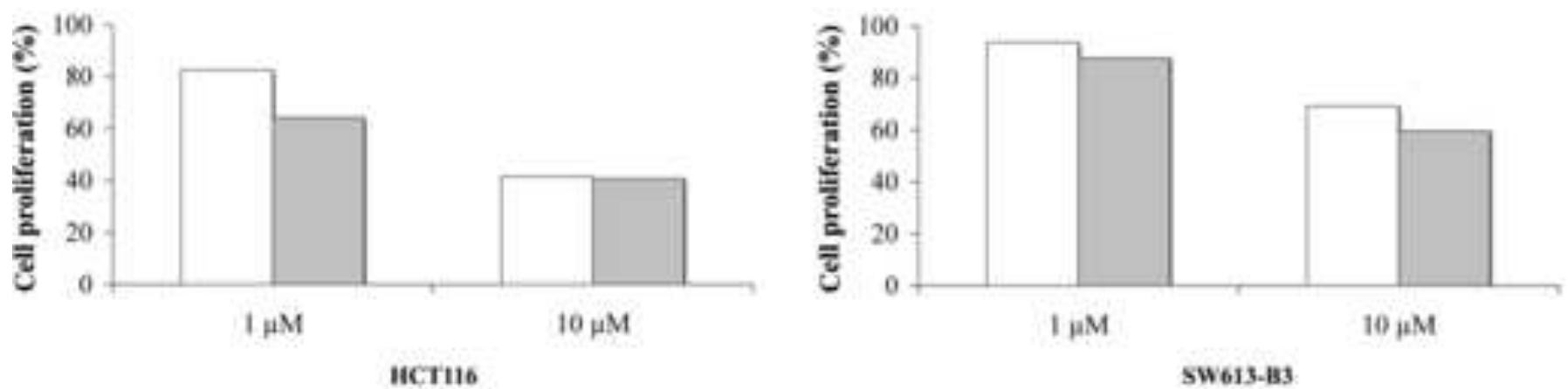

G

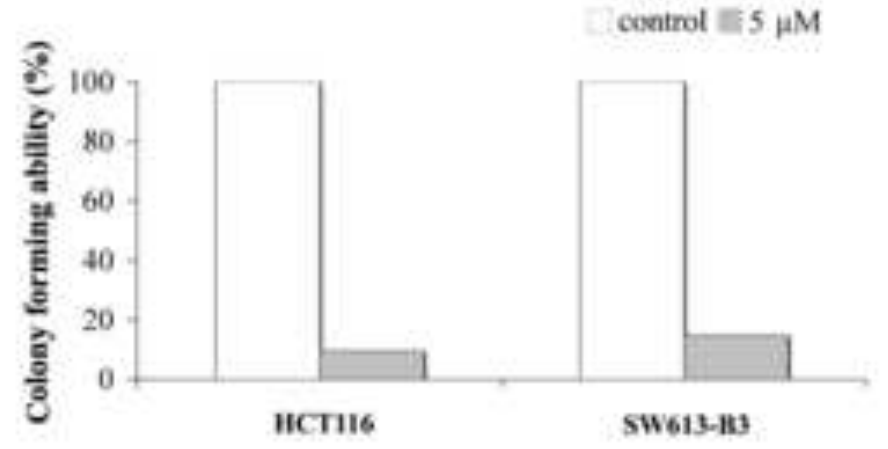

Fig. 1 

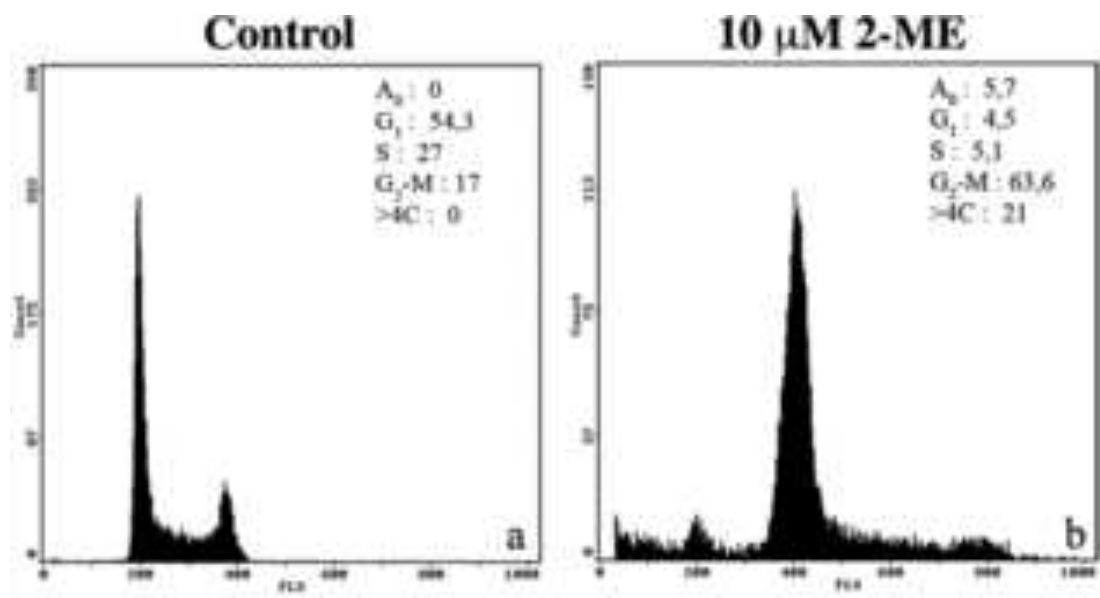

$24 \mathrm{~h}$
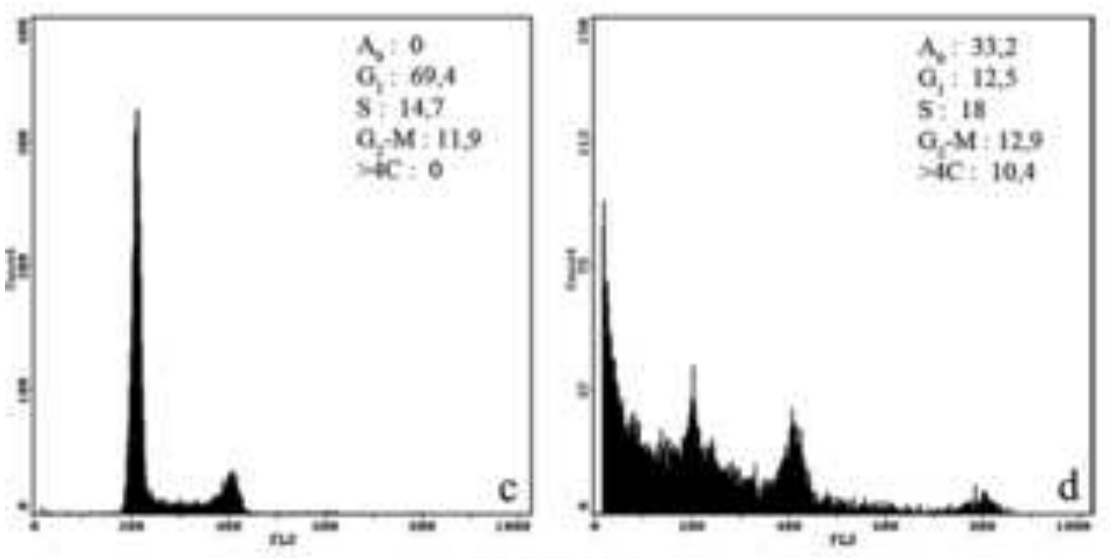

$24 h+24 h$

\section{HCT116}

Control
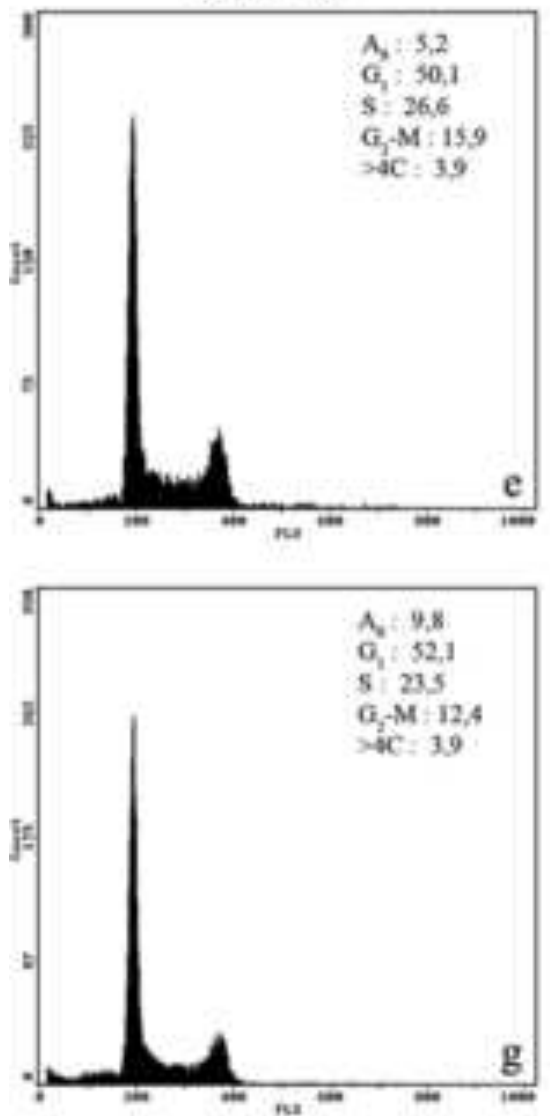

$10 \mu \mathrm{M}$ 2-ME

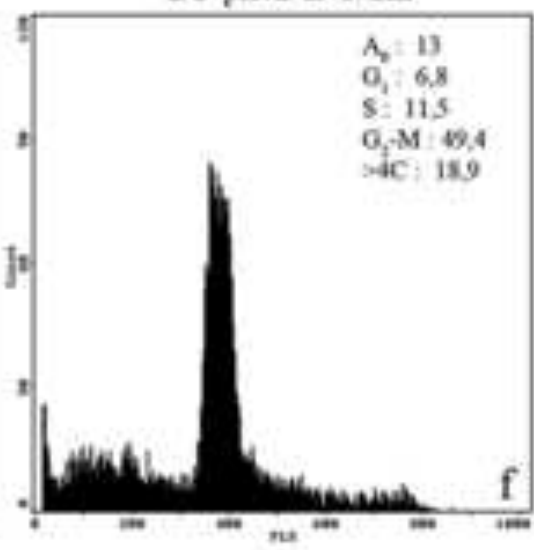

Ai: 19.2
$Q_{1}=26,8$

s: 213

O. M: 11,4

$>+C=15,8$

$24 \mathrm{~h}+24 \mathrm{~h}$

$24 \mathrm{~h}$

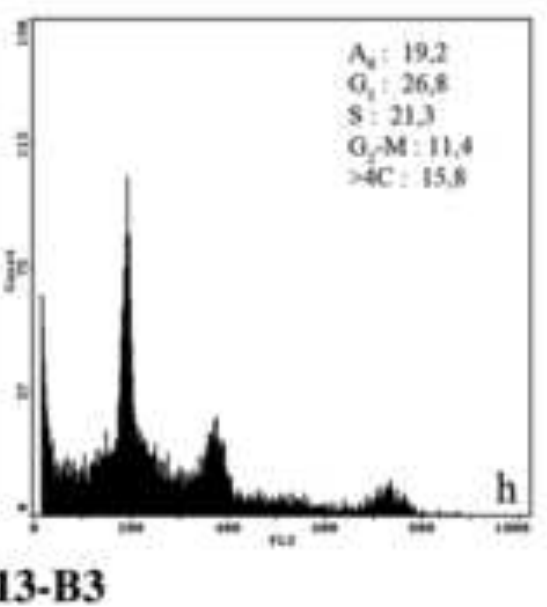

Fig. 2 


\section{A \\ A}
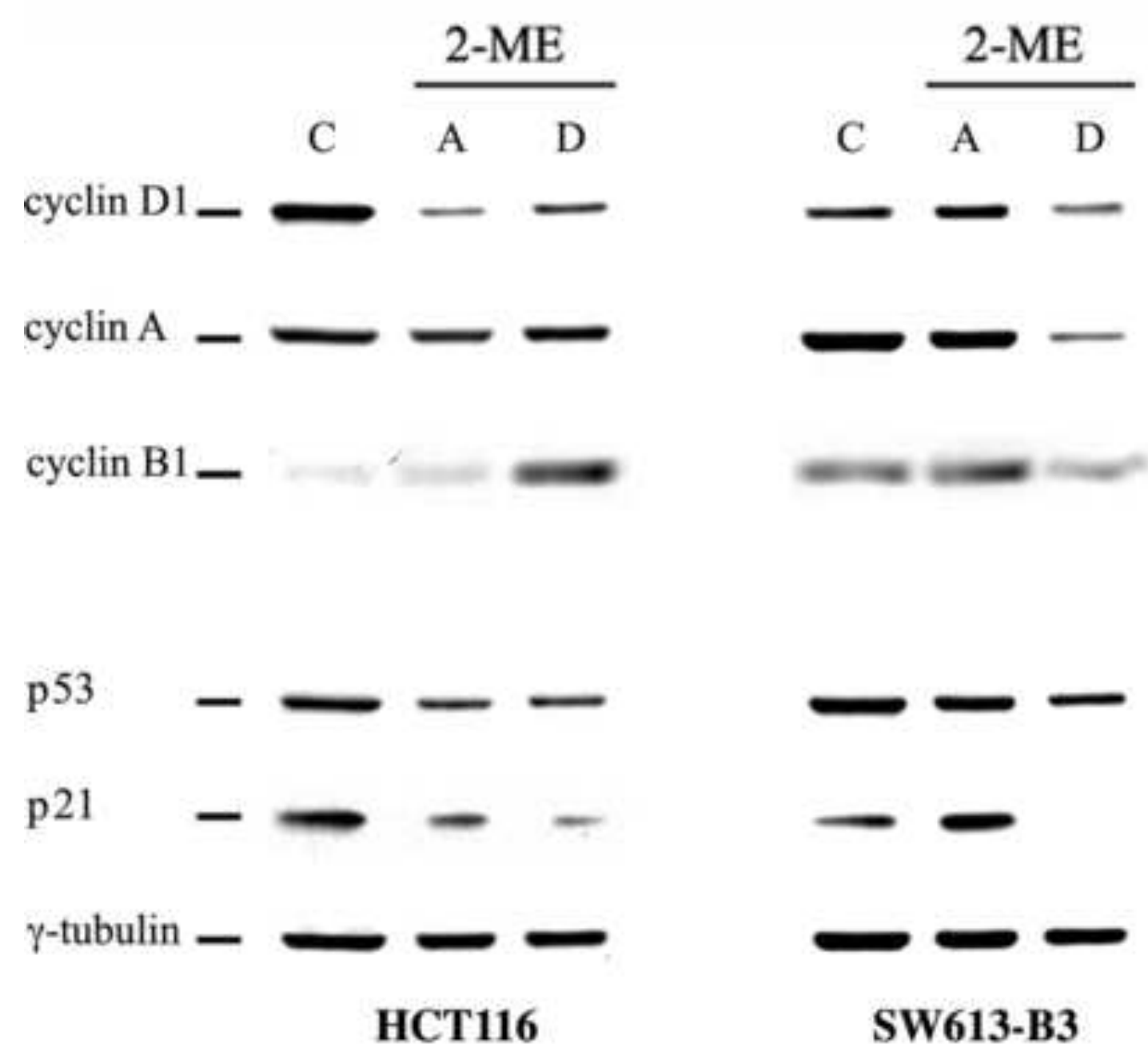

2-ME

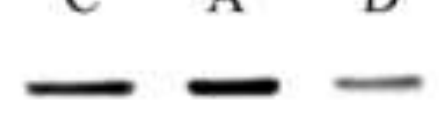

ansen
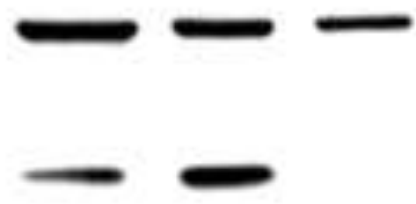

SW613-B3

B

\begin{tabular}{|r|c|c|c|c|c|} 
HCT116 & cyclin D1 & cyclin A & cyclin B1 & p53 & p21 \\
\cline { 2 - 6 } C & 1.0 & 1.0 & 1.0 & 1.0 & 1.0 \\
A & 0.2 & 0.8 & 1.4 & 0.6 & 0.5 \\
D & 0.4 & 1.1 & 4.0 & 0.6 & 0.2 \\
\hline
\end{tabular}

SW613-B3

\begin{tabular}{|l|l|l|l|l|l|}
\hline C & 1.0 & 1.0 & 1.0 & 1.0 & 1.0 \\
A & 1.4 & 1.0 & 1.4 & 0.9 & 2.1 \\
D & 0.7 & 0.2 & 0.7 & 0.7 & 0.0 \\
\hline
\end{tabular}

Fig. 3 
Control

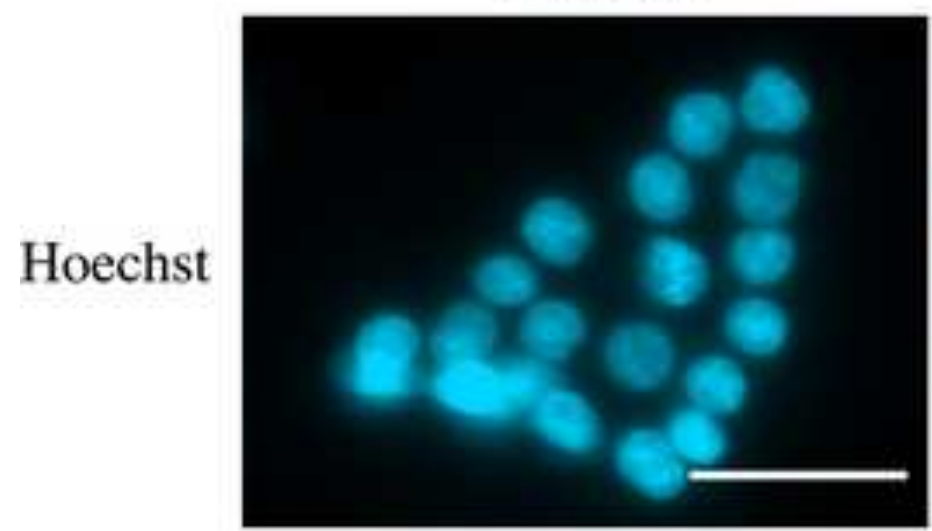

P-H3

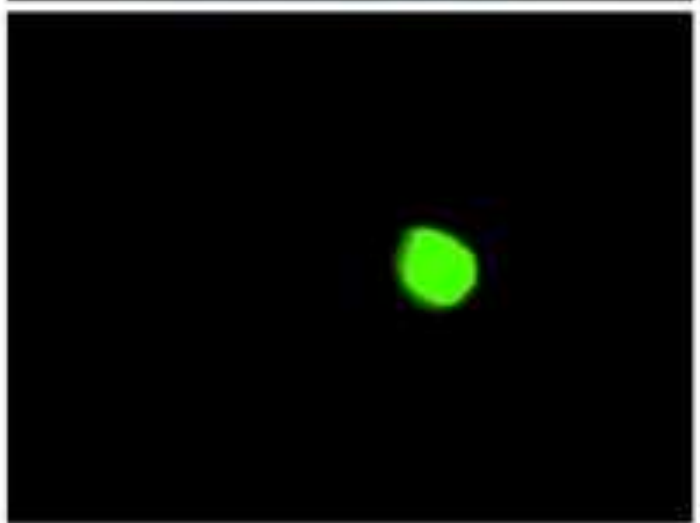

$10 \mu \mathrm{M} 2$-ME
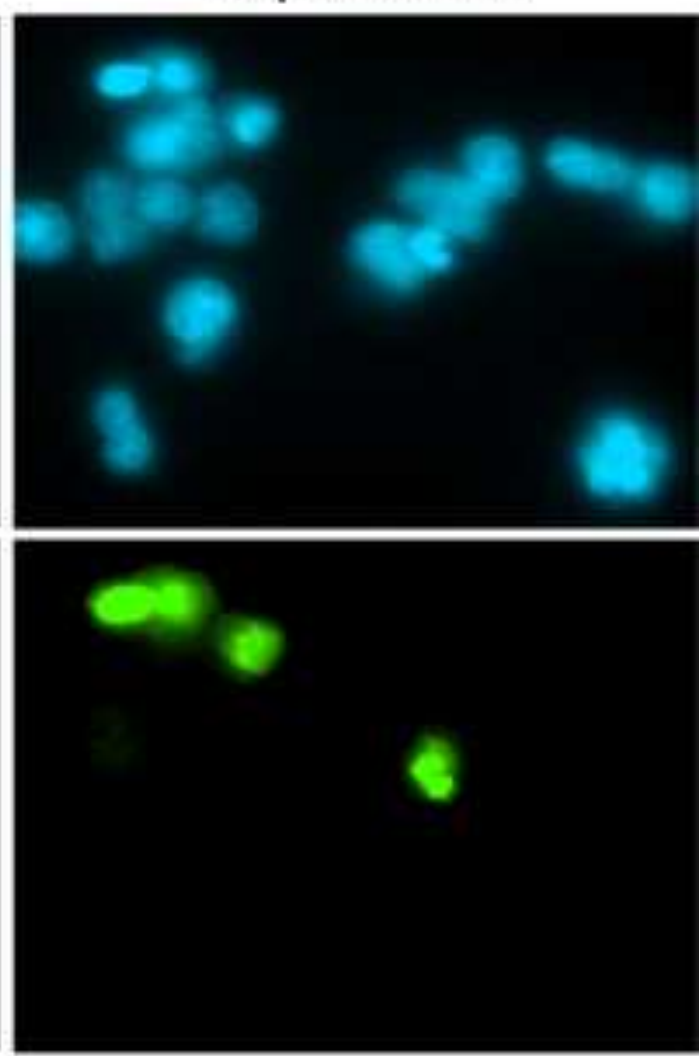

HCT116

Control

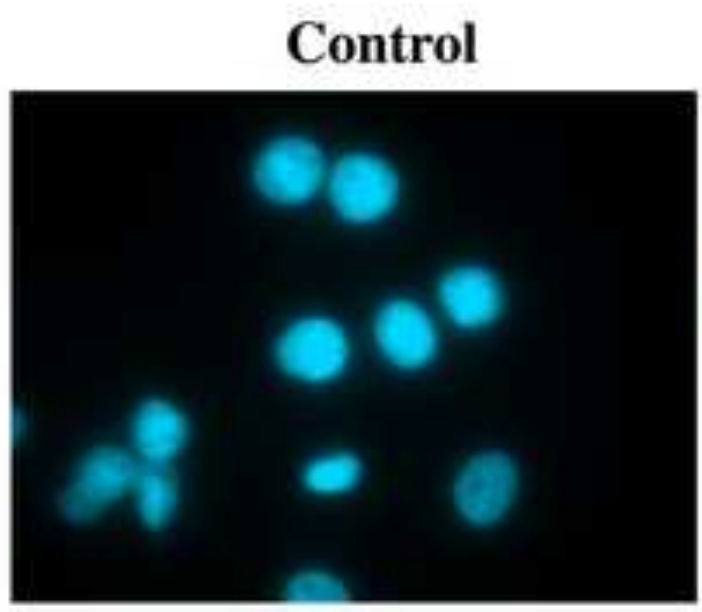

Hoechst

P-H3

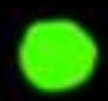

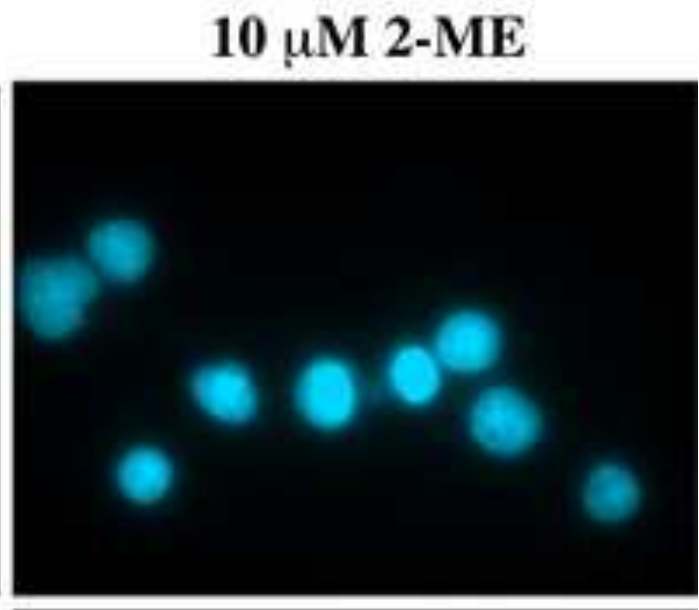

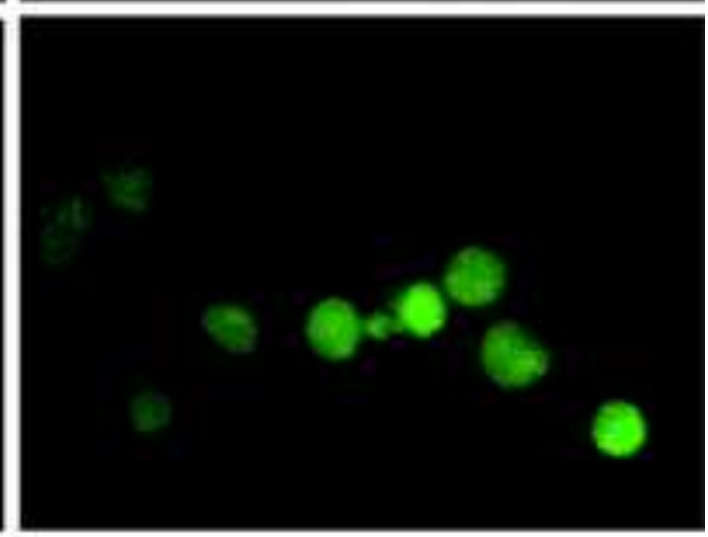

SW613-B3

Fig. 4 


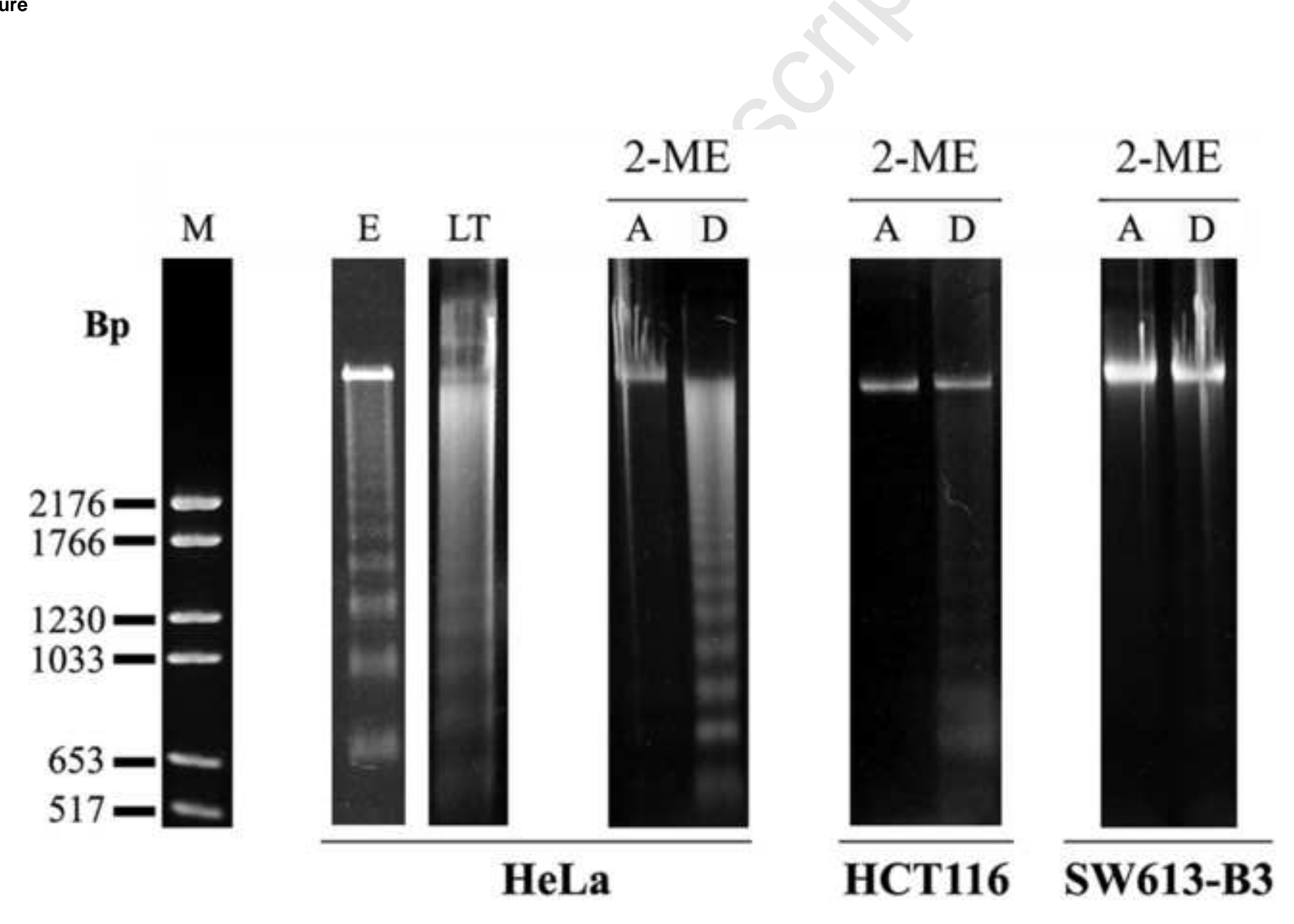

Fig. 5

HCT116 SW613-B3

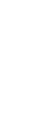

-

ra

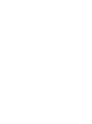

2-ME 2-ME 2-ME

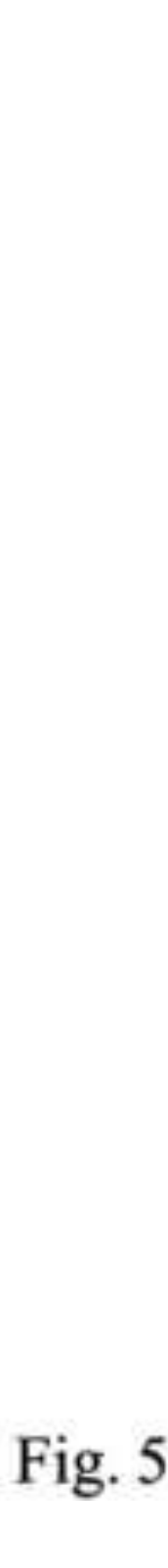

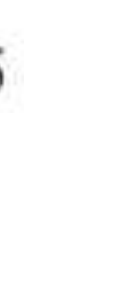




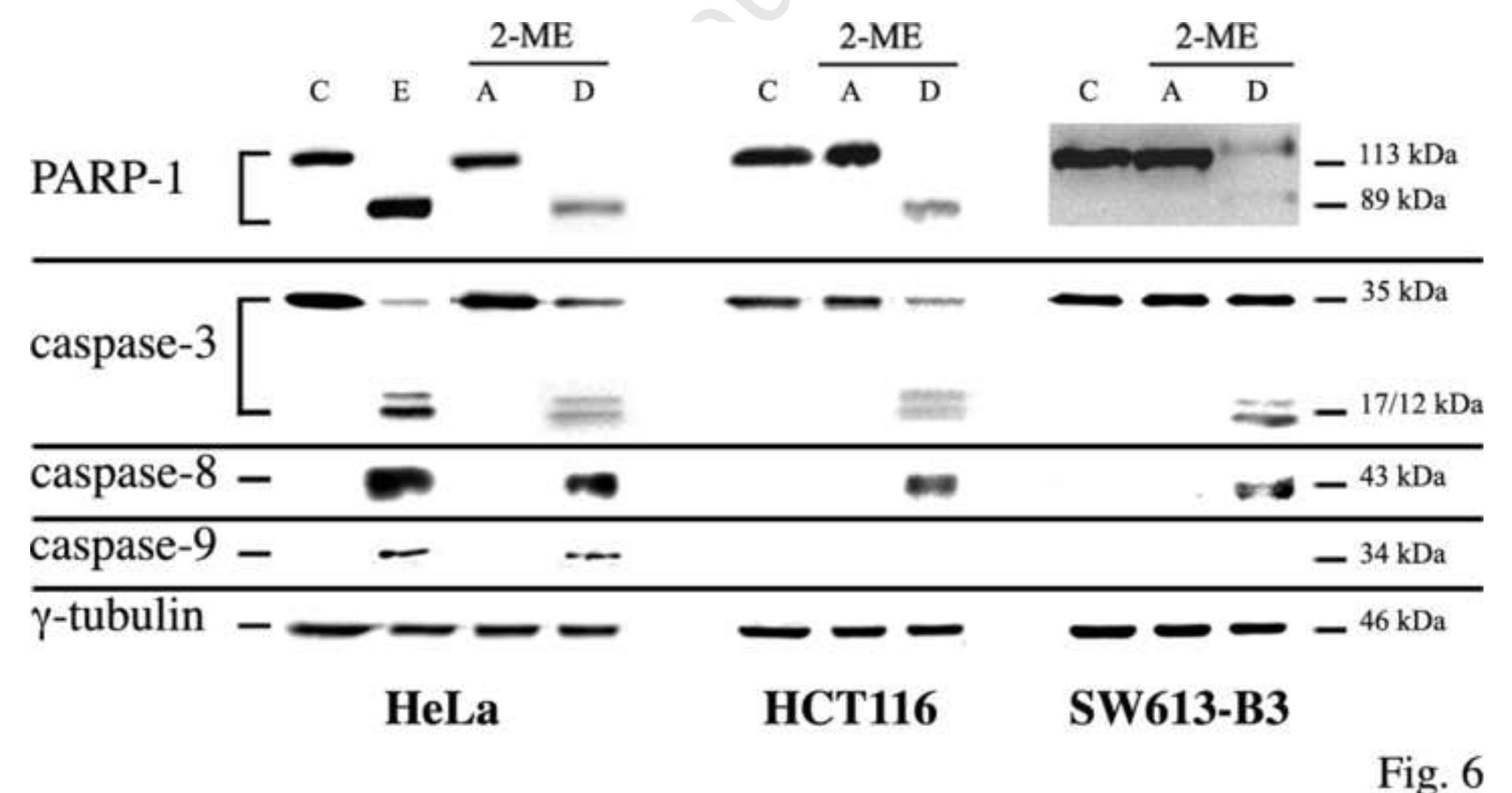

Fig. 6 

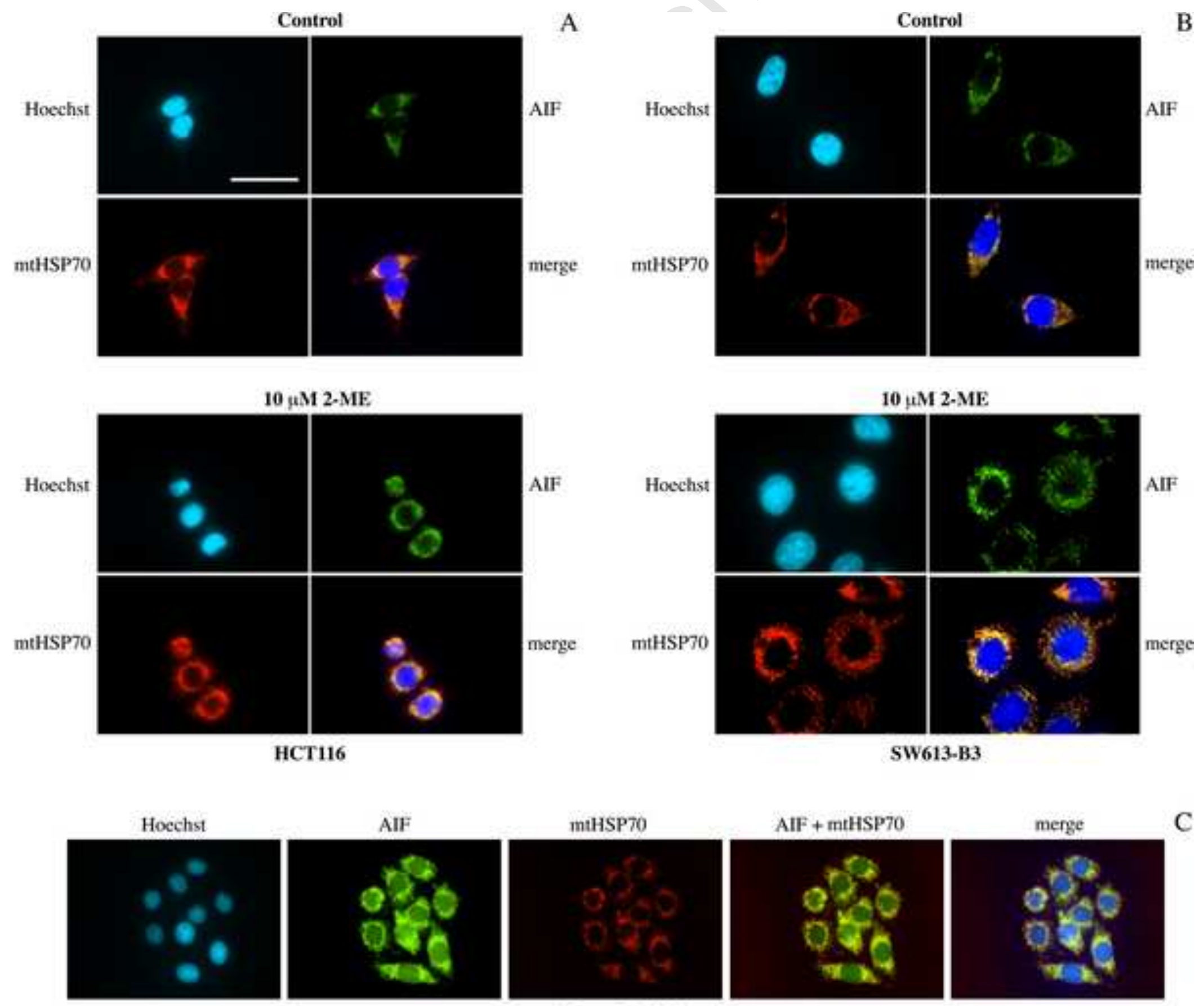

HeLa + RS2780 